\title{
Circulação de intelectuais e recepção das novas ciências do homem francesas no Brasil: 1908-1932
}

\author{
Marcia Consolim* \\ https://orcid.org/0000-0002-3622-073X
}

\begin{abstract}
O professor francês falou sobre o preparo cientifico dos professores desenvolvido na Escola Normal Superior, em que atuava, e nas demais escolas, na França, e ainda sobre o ensino superior de seu país. [...] O professor Ovidio [...] lembrou aos presentes que as então recentes criticas de Gustave Le Bon aos métodos franceses de ensino haviam sido desmontadas pela conferência do professor Drouin. A conferência e as palavras de Campos foram muito aplaudidas, sob a assistência e parte da colônia francesa que estava presente.
\end{abstract}

Sessão da Sociedade de Educação de São Paulo em 1924, em Nery, 2008, p. 37.

Introdução

Neste artigo analiso alguns aspectos das relações intelectuais entre a França e o Brasil a partir da circulação de psicólogos e de sociólogos franceses no país no período anterior ao da fundação das universidades. Adoto uma abordagem que escapa tanto à chave de leitura da história das ideias quanto à chave de leitura puramente institucionalista, ao enfatizar o papel das redes de sociabilidade e dos projetos educacionais conjuntos, assentados em instituições escolares e culturais, que organizam uma das formas de introdução das ciências do homem francesas no Brasil. Procuro articular os estudos sobre educação e os estudos sobre história das ciências sociais - 
algo pouco praticado em razão da especialização disciplinar e da institucionalização dessas ciências no ensino superior. Trata-se, portanto, de borrar um pouco essas fronteiras, a fim de mostrar um traço de continuidade no processo de incorporação e de institucionalização dessas ciências no Brasil.

Sob o pano de fundo do movimento internacional denominado Escola Nova, bem como das reformas que ocorrem simultaneamente no ensino primário, secundário e nas escolas normais da França e do Brasil nos anos 1920, trata-se de mostrar que as relações estabelecidas entre as elites intelectuais de ambos os países, condicionadas por sua posição nos respectivos contextos nacionais, resultaram na incorporação da sociologia e da psicologia científica francesa no país. Como essas relações científicas e intelectuais são hierárquicas, ou seja, entre um país dominante e um país dominado, as estratégias dos professores franceses e dos educadores reformistas foram diversas, mas complementares. Aos professores franceses era imperativo construir uma trajetória internacional por razões de dever cívico e de obtenção de reconhecimento científico no exterior: a precariedade da universidade francesa no período entreguerras aliava-se à progressiva perda de legitimidade das novas ciências humanas francesas diante de suas congêneres anglo-saxônicas. Aos educadores reformistas no Brasil era preciso estabelecer vínculos que legitimassem sua nova formação a fim de erigir barreiras contra os "autodidatas" ou "diletantes". Esse processo leva ao reconhecimento dos embates envolvendo grupos intelectuais estrangeiros e ao emprego dessas oposições para fins de legitimação no contexto nacional.

Grande parte da produção intelectual e dos embates nesse período se deu pela imprensa, em razão da expansão do mercado cultural, cuja análise é fundamental para a compreensão da história intelectual do período. No Brasil, a atividade jornalística não era prática contraditória à atuação propriamente científica, mas um de seus alicerces, pois mesmo as recém-criadas revistas científicas ou de educação reproduziam artigos já publicados pela imprensa. Além disso, o acesso à imprensa estrangeira por parte das elites locais permitia acompanhar os embates intelectuais em outros países e tomar partido - reação associada à sua posição no campo do poder nacional. Por outro lado, os educadores reformistas também consumiam as revistas científicas estrangeiras mais especializadas, tentando fundar no país um mercado para difusão e consumo restrito no domínio das "ciências da educação" - biologia, psicologia e sociologia. Assim, acumulavam-se referências e preferências que se inscreveram nas instituições de formação e de atuação profissional.

No contexto do movimento escolanovista, movimento internacional com impactos específicos em cada país, as publicações na área das novas ciências do homem se desdobraram entre uma vertente com tendência "pura” ou "teórica” e outra "aplicada" ou "empírica" - gêneros que foram associados à produção, respectivamente, 
da França e dos Estados Unidos nos anos 1920. Ou seja, o debate sobre as ciências do homem no período entreguerras estava necessariamente impregnado de valores políticos associados à nação e à disputa entre países dominantes pela definição legítima no domínio dessas ciências. No caso do Brasil, essa oposição adquiriu contornos específicos: o círculo intelectual do OESP e da Escola Normal de São Paulo aderiu ao modelo francês, enquanto o círculo da Escola Normal de Pernambuco e do Colégio Pedro II ao estadunidense. De modo que as disputas entre os países dominantes se reproduziram até certo ponto no contexto nacional.

Argumento que o enraizamento das ciências do homem francesas no Brasil deve ser compreendido à luz de vários processos nacionais e internacionais. Em primeiro lugar, entende-se que as missões científicas são portadoras tanto dos interesses do Estado francês quanto dos interesses associados à posição dos professores franceses no ensino superior e nas hierarquias disciplinares - posição dominante do ponto de vista institucional, mas dominada pela falta de legitimidade das novas ciências do homem relativamente às disciplinas tradicionais no plano nacional e ameaçada pelas ciências sociais norte-americanas no plano internacional. Em segundo lugar, entende-se que a posição dos educadores brasileiros - dominante em termos sociais, mas dominada no campo do poder - gerou estratégias que culminaram na diferenciação crescente das elites dirigentes, entre as quais se destacam os investimentos na difusão da psicologia e da sociologia da educação. Em terceiro lugar, e este é o ponto central, defendo que a homologia de posição entre os professores franceses e um grupo específico de educadores reformistas, do círculo de São Paulo, favoreceu a afinidade de interesses pela institucionalização das novas ciências do homem francesas (Bourdieu, 1984; 2002). Essa homologia criou condições para o trabalho dos intermediários culturais de ambos os países - conferências, artigos, traduções, colunas de jornal etc. - , a fim de legitimar as ciências francesas em combate contra as ciências estadunidenses. Concluo que essas ações obtiveram uma vitória parcial em razão da crescente diversificação de modelos estrangeiros difundidos no país - em particular a partir das missões dos educadores brasileiros rumo aos Estados Unidos desde a segunda metade dos anos 1920 .

$\mathrm{Na}$ primeira seção, trato dos interesses propriamente políticos associados às missões francesas - a competição com a Alemanha e os Estados Unidos -, a fim de mostrar que essa é uma dimensão fundamental, ainda que não suficiente, para compreender as relações científicas e intelectuais entre os dois países. Na segunda seção, abordo o papel central desempenhado por Georges Dumas (1966-1946) na constituição de redes no Brasil e identifico três grupos de apoiadores que ocupavam posições no campo do poder - entre os quais os educadores reformistas. Na terceira seção, analiso os textos publicados pelos professores franceses na imprensa com o 
objetivo de difundir as ciências do homem francesas e mostro que seu sentido está no combate ao modelo educacional norte-americano. Na quarta seção, identifico as instituições em que se enraizou o modelo educacional francês e, particularmente, a progressiva diferenciação dessa recepção entre os grupos dominantes no campo do poder, adeptos da "cultura francesa", e os educadores ligados às escolas normais, adeptos da "ciência francesa". Finalmente, analiso as práticas editoriais dos educadores reformistas a fim de mostrar que a tradução de autores estrangeiros deve ser entendida como resposta às missões francesas dos anos 1920, uma estratégia cujo fim era a legitimação de suas próprias trajetórias. Os tópicos a seguir investigam progressivamente as diversas dimensões das relações internacionais - política, social e cultural - pelas quais se procura refinar o entendimento dessa recepção a partir de condicionantes internacionais, nacionais e locais.

\section{As Missões Científicas Francesas no Brasil: embaixadores e pesquisadores}

Os estudos sobre as relações científicas entre a França e o Brasil costumam caracterizar as missões francesas como parte da "diplomacia intelectual" em razão da participação direta ou indireta do Estado francês nessas iniciativas (Petitjean, 1989; Charle, 1994; Hamburguer 1996; Suppo, 2001). Contudo, as missões científicas de curta duração foram pouco estudadas e, em geral, consideradas de pouca importância para o enraizamento de uma ciência ou prática científica estrangeira no país (Massi, 1989). Além disso, a função diplomática que elas desempenharam pareceu ter excluído as transferências propriamente científicas - ainda mais quando se considera que não havia centros de formação superior nas novas ciências do homem no Brasil. Contudo, o papel do "embaixador" e o do "pesquisador" não são excludentes, de modo que é preciso analisar mais detidamente as funções realizadas pelos professores franceses nos anos 1920 sem as quais provavelmente não haveria missões universitárias na década seguinte (Charle, 1994; Charle et al., 2004).

A mobilidade internacional de professores franceses em direção aos Estados Unidos e à América Latina, iniciada pouco antes da Primeira Guerra, foi motivada pela rivalidade com a Alemanha, o que revela a importância do nacionalismo nesse período. Nos anos 1920, a presença francesa no Brasil envolve claramente uma disputa com os Estados Unidos pela definição legítima da estrutura e função do sistema educacional, da formação de professores e das "ciências da educação" - aí incluídas as novas ciências do homem (Charle et al., 2004; Silva, 2011; Rocha, 2016). Os professores franceses precisavam oferecer cursos e modelos alternativos ao já estabelecido em algumas escolas normais - inspirado no pragmatismo estadunidense. Assim, cabia aos professores de psicologia e de sociologia universitária uma tarefa 
das mais essenciais e das mais difíceis - transplantar um modelo educacional e um conjunto de categorias científicas em um país estrangeiro - em um momento em que o centro da produção científica nessa área se deslocava para os Estados Unidos (Paicheler, 1992).

França e Estados Unidos também se opunham em termos de política de internacionalização. Em oposição ao modelo estadunidense, em que a circulação internacional era majoritariamente financiada por grandes instituições filantrópicas, as missões francesas estavam atreladas predominantemente ao Estado, que atuou direta ou indiretamente em prol da dominação intelectual francesa no Brasil desde o início do século Xx. Entre 1908 e 1917, as atividades foram centralizadas pela Universidade de Paris, enquanto no período entreguerras o Ministério das Relações Exteriores francês centralizou o conjunto das ações, o que resultou em uma atuação muito mais ampla e diversificada em termos geográficos e disciplinares. A expectativa por trás dessa política de Estado havia sido difundida em publicações do Partido Radical francês: a dominação intelectual e científica na América Latina seria um meio para a dominação política e econômica na região (Dumas, 1924). Assim, foi constante a troca de informações entre os professores franceses e membros do Ministério das Relações Exteriores da França sobre as iniciativas dos países “rivais”, os Estados Unidos e a Alemanha, na área científica e educacional - questão presente na correspondência diplomática de todo esse período ${ }^{1}$. Desse modo, observa-se um processo contraditório de ampliação dos espaços internacionais de trocas científicas e intelectuais baseadas em grande parte na concorrência e na exportação de modelos e de práticas científicas e intelectuais nacionais (Charle, 1994; 2004; Heilbron et al., 2009).

A extensão das missões científicas francesas revela a grandiosidade do investimento por parte do governo francês². Entre 1908 e 1938, vieram ao Brasil aproximadamente 55 professores de faculdades de medicina, letras, ciências e direito, além do Collège de France, para cursos de dois meses de duração ${ }^{3}$. A escolha dos nomes

1. Veja-se, por exemplo, um trecho de carta enviada por Georges Dumas ao Ministério das Relações Exteriores: "Seria injusto dizer que os Norte-Americanos trabalham contra nós, mas pode-se afirmar que eles difundem uma cultura de base moral e prática e um conhecimento do inglês que não prepara os estudantes para receber e amar nossa influência. No Rio, ouve-se nos meios mais ou menos americanizados [...] que é preciso homens de ação e de realidade, e se a juventude aceitar essa filosofia prática e simplista nós certamente a perderemos". Cf. Dumas ao Ministério das Relações Exteriores. MAE. 1917. Sobre as relações com a Alemanha, vejam-se: Silva, 2013, e Muñoz, 2020.

2. Os dois principais institutos de promoção e financiamento dessa circulação foram o Instituto Franco-Brasileiro de Alta Cultura (1922-1938), baseado no Rio de Janeiro, e o Instituto Técnico Franco-Paulista (1925-1928). As missões de Piéron e de Fauconnet para São Paulo, mencionadas adiante, ocorreram no âmbito do ITFP - claramente afinado com as orientações das elites dirigentes que demandavam "ciência aplicada". Cf. Suppo, 2001; Petitjean, 1989; Vercesi, 2010.

3. Cf. Suppo (2001) para a lista dos professores franceses e dos professores brasileiros que foram para 
era sugerida pelo país anfitrião e a vinda dependia do aceite do professor convidado e de Georges Dumas - que sugeria novos nomes em caso de impossibilidade. Em razão da mediação de Dumas na seleção dos candidatos, não surpreende o fato de que a maioria absoluta dos recrutados fosse oriunda das faculdades de medicina e de letras, áreas de sua formação, o que lhe permitiu rentabilizar seu capital social e simbólico na França e favorecer sua eleição à Academia de Ciências Morais e Políticas e à Academia de Medicina ${ }^{4}$. O contrato dos professores para a vinda ao Brasil era de 25 mil francos (divididos em partes iguais entre os dois governos), o que equivalia aproximadamente a quatro meses de salário de um professor em fim de carreira à época - o que tornava a viagem economicamente atrativa, considerando-se que os cursos ocorriam no período de férias escolares na França. A despeito das vantagens materiais e simbólicas, é preciso levar em conta os interesses específicos dos professores franceses, associados à disciplina e à posição de sua disciplina no contexto francês - interesses nem sempre confluentes ao da expansão da cultura francesa ${ }^{5}$.

\section{Redes francófilas e afinidades científicas: engenheiros, médicos e educadores}

Georges Dumas teve um papel fundamental como intermediário cultural nas relações França-Brasil desde sua primeira visita ao país, em 1908, até o fim dos anos 1930. Sua figura é central tanto porque centraliza objetivamente as relações institucionais entre os governos e os sistemas de ensino dos dois países, quanto porque possui as propriedades sociais e intelectuais apropriadas a um país como o Brasil - cujas carreiras e competências acadêmicas ainda não estavam profissionalizadas e delimitadas de maneira estrita. Filósofo e médico psiquiatra, além de normalista e professor da Sorbonne, Dumas tornou-se "psicólogo" em um momento em que essa denominação credenciava tanto as atividades literárias quanto as científicas. Seus cursos na Sorbonne eram ministrados no Hospício Santa Ana, à moda de Jean-Marie Charcot, e eram seguidos pela "boa sociedade" parisiense, por intelectuais e estudantes universitários. Entre

a França - uma vez que o Instituto Franco-Brasileiro de Alta Cultura abrangia a circulação nos dois sentidos.

4. Dumas é eleito membro livre da Academia de Medicina em 1926 e membro titular da Academia de Ciências Morais e Políticas em 1933. Nos dois casos, os “serviços prestados à França” foram enfatizados pelos acadêmicos que indicaram seu nome.

5. Desde os anos 1910, a psicologia experimental francesa já tinha prestígio nos Estados Unidos - dado que os estudos de Binet e Simon haviam sido amplamente difundidos e adaptados aos interesses da escola estadunidense. No caso da sociologia, o diálogo se estabeleceu com os concorrentes de Durkheim - Tarde e Worms -, o que gerou um ambiente antidurkheimiano até os anos 1930. Isso talvez explique que a primeira tradução americana das Regras do Método Sociológico seja de 1938 - um ano depois da tradução brasileira. (Cf. Paicheler, 1992; Tournès, 2007; Turner, 2010; Platt, 1995). 
seus alunos, alguns médicos brasileiros - Manuel Bomfim e Maurício de Medeiros -, dos quais partiu o convite para uma primeira visita ao Brasil, em 19086. Tudo indica que a própria hexis corporal de Dumas contou para a escolha de seu nome por parte da universidade francesa ${ }^{7}$ : originário do Sul da França, com modos mediterrâneos e traços "latinos", encarnava um "francês à brasileira" - celebrado pelos jornais da época como sinal de proximidade entre os dois países. Do lado francês, essa proximidade foi percebida com condescendência: Dumas foi retratado pelos colegas franceses como uma espécie de "maestro" dos intelectuais brasileiros e um "grande servidor da causa francesa" ${ }^{8}$. Assim, era um "intermediário cultural” de tipo específico: ocupava posição dominante no campo universitário como professor da Sorbonne, mas exercia funções subordinadas no campo científico de seu próprio país. ${ }^{9}$

Os professores franceses foram recrutados em geral nas posições dominantes do ensino superior francês e tinham poucas expectativas em relação aos colegas brasileiros. Considerando-se apenas os professores de psicologia e de sociologia, vieram ao Brasil nos anos 1920 cinco professores - da Sorbonne ou do Collège de France -, um grupo com propriedades intelectuais muito semelhantes, que participava dos mesmos círculos intelectuais e publicava nas mesmas revistas ${ }^{10}$. Formados pela Escola Normal Superior, agrégés e portadores de dois títulos de doutorado (em Filosofia e Ciências ou

6. Especula-se que Dumas tenha sido escolhido por ter publicações sobre Augusto Comte. De fato, sua tese secundária é sobre Comte, e ele publica uma obra sobre Comte e Saint-Simon em 1906. Comte é objeto de seus primeiros cursos no Brasil, nos quais ele advoga fartamente em prol do Comte científico em detrimento do fundador da religião da humanidade. Suas aulas geraram protestos e causaram indignação nos meios ortodoxos. Sobre o convite a Dumas, cf. Melo \& Campos, 2014.

7. Na verdade, Dumas veio por intermédio de uma instituição fundada em 1907 denominada Groupement des Universités et Grandes Écoles de France pour les relations avec l'Amérique Latine. Sobre o Groupement ver Suppo (2001) e Petitjean (1989; 2011).

8. O necrológio de Pierre Janet, professor do Collège de France, colega e grande amigo de Dumas, é bastante direto a esse respeito: "Seu principal esforço se deu na organização das relações científicas e culturais entre os países da América do Sul e da França. [...] Aceitaram facilmente as condições propostas por ele, seguiram suas orientações, mesmo com dificuldades [...]. Dumas chegava com as soluções prontas, com programas bem preparados. Trata-se da conduta dos chefes, pois economiza-se o trabalho de reflexão e de escolha entre os que escutam, tirando-lhes as dúvidas. Como ele informava que voltaria no ano seguinte, isso impunha a continuidade dos esforços e o acompanhamento do trabalho". Janet sobre Dumas. Arquivos do Collège de France. Fundo Pierre Janet. 55-CDF - 18 a - c.

9. Dumas foi também editor de manuais de psicologia e seu veio pedagógico se destaca entre todas as suas atividades acadêmicas. O conjunto dos necrológicos sublinha o papel do "gestor intelectual" ou do "professor" - além de seu caráter diplomático - traços que ocupam posição dominada na hierarquia científica.

10. Entre os cinco professores encontram-se três psicólogos - Georges Dumas, Henri Piéron e Pierre Janet - e um sociólogo - Paul Fauconnet - e o filósofo Lucien Lévy-Bruhl. Pierre Janet e Lucien Lévy-Bruhl estiveram no Brasil por ocasião das comemorações do Centenário da Independência, mas não há traço de um possível curso nessa década. 
em Filosofia e Medicina), possuíam todos os trunfos do ponto de vista das hierarquias científicas e intelectuais. Oriundos de famílias com trajetórias ascendentes por meio da escola republicana, a ela tudo deviam e por ela estavam prontos a exercer funções diplomáticas. Contudo, enquanto praticantes das novas ciências humanas, sociologia e psicologia, sua posição era dominada no campo disciplinar, de modo que estavam em combate pela legitimação e institucionalização dessas ciências contra as disciplinas tradicionais, a história e a filosofia, em todos os níveis de ensino. Lutavam pelo fim da filosofia espiritualista e da filosofia moral - centradas na consciência individual ou na consciência moral -, em nome do estudo objetivo dos fatos (psicológicos ou sociais). A posição e os embates em que se envolveram reforçaram seu interesse pela circulação internacional à medida que era uma oportunidade para se fazer um nome pelas bordas do sistema científico internacional.

Do lado brasileiro, não era natural a adesão das elites dirigentes às iniciativas do governo francês na área educacional, pois havia inúmeras diferenças entre os sistemas educacionais de ambos os países. No caso do Brasil, o ensino primário era descentralizado, as instituições públicas de ensino secundário eram raras e desorganizadas e, além disso, não existiam universidades constituídas; no que diz respeito à formação de professores, não havia concursos ou programas padronizados, e as carreiras não eram profissionalizadas. Além disso, as relações entre intelectuais e Estado eram muito distintas nos dois países. No caso do Brasil, as trajetórias dos educadores e professores do ensino médio e superior acumulavam em geral outras funções dirigentes: na administração pública, na produção intelectual livre, na política e mesmo na vida econômica do país. Do ponto de vista ideológico também havia barreiras para essa aproximação: dado o espírito nacionalista vigente, temia-se qualquer iniciativa com ares imperialistas por parte dos países centrais ${ }^{11}$.

A primeira geração que acolheu Dumas e a mais receptiva às suas iniciativas é proveniente do ensino superior - engenharia, medicina e direito - e estava familiarizada com a produção intelectual francesa porque havia estudado na Europa ou participara de congressos internacionais antes mesmo da chegada de Dumas. Contudo, é preciso diferenciar esses meios segundo a posição social e intelectual de seus membros, pois esse fator interferiu nas modalidades de circulação das obras francesas na área de educação. $\mathrm{O}$ meio dos engenheiros é formado por grandes proprietários ou diretores

11. Um ponto sensível foi o Lyceu Franco-Brasileiro de São Paulo, cuja fundação foi condicionada à restrição do número de professores e diretores franceses. Em 1921, Dumas exprime esses constrangimentos: "O Sr. Dumas insistiu relatar que não se tratava absolutamente de introduzir na América Latina o ensino puramente da língua francesa, mas de associar-se a uma obra comum na qual os franceses concorrerão [para] certos pontos, como por exemplo no ensino de humanidades, de retórica e de filosofia nos moldes do ensino nacional francês. (Havas)". Dumas, Correio Paulistano, 10 de janeiro de 1921. 
de empresas na área de infraestrutura (água, luz, gás, saneamento, ferrovias etc.) e representa o grupo mais abastado entre os amigos de Dumas. Muitos deles haviam se formado em escolas de engenharia ou de belas-artes no exterior, em particular na França ou na Bélgica e, uma vez no Brasil, expressavam sua francofilia predominantemente por meio do mecenato ou de patrocínios diversos a fim transplantar no país o estilo de vida assimilado no exterior. Assim, as instituições que fundaram, seja a União Escolar Franco-Paulista (1908), que financiou os cursos sobre Brasil na Sorbonne, seja o Lyceu Franco-Brasileiro de São Paulo ${ }^{12}$ (1923), tinham por finalidade difundir a língua e a cultura entre os dois países ${ }^{13}$. Nesse meio encontram-se muitas personalidades com vínculos diretos ou indiretos com empresas que disputavam espaço em grandes empreendimentos na área de obras públicas em São Paulo e no Rio de Janeiro - por exemplo, com a Cia. Docas de Santos, concorrente da canadense São Paulo Light Co. -, que se valiam da crítica ao capital estrangeiro para defender seus interesses ${ }^{14}$. Esse meio está presente em algumas instituições centrais para os educadores, tais como a Liga Nacionalista de São Paulo ${ }^{15}$. Contudo, não era esse o meio mais interessado na contribuição das novas ciências do homem para a educa-

12. Na origem do Lyceu encontra-se uma composição entre o capital nacional e internacional que se exprime por meio de redes de relações pessoais e profissionais. Um dos patrocinadores do Lyceu, Quellenec, engenheiro chefe da Cia. Canal de Suez e membro da direção da Rio Light Co., é colega nesta empresa de Alfredo Maia - antigo secretário de Obras Públicas do governo do estado de São Paulo e vice-presidente da E. F. Sorocabana e da Sorocabana Railway Co. Por sua vez, Antônio Francisco de Paula Souza, pai do diretor do Liceu, Ruy de Paula Souza, havia sido ministro da Indústria e Obras Públicas e diretor da superintendência de Obras Públicas do estado de São Paulo na mesma época de Alfredo Maia.

13. Os principais membros da União Escolar são: Ramos de Azevedo (Politécnica); Ruy de Paula Souza e MC Buarque (Escola Normal); Reynaldo Porchat (Direito); Américo Brasiliense e João Frederico de Borba (Farmácia); José Carlos de Macedo Soares e Oscar de Sá Campelo (Comércio); Otávio Teixeira Mendes e Francisco Dias Martins (Agricultura). Sobre as atividades da União Escolar Franco Brasileira, cf. Jornal do Commercio, 14 ago. 1921. Os principais financiadores do Liceu foram os seguintes, em ordem de grandeza do patrocínio: Société Anonyme Française des Lycées Franco-Brésiliens; Ramos de Azevedo; Lineu de Paula Machado; Victor da Silva Freire; Luiz A. C. Galvão; Carlos Botelho; Arnaldo Dumont Villares; José de Sampaio Moreira; Alfredo Pujol; Luiz Betim Paes Leme; Pio de Almeida Prado; Ruy de Paula Souza; Senador Vicente de Paula de Almeida Prado; José V. de Almeida Prado Júnior; Lupercio Teixeira Camargo; Julio de Mesquita; João Alves Lima. Cf. Vercesi, 2010, p. 26.

14. Veja-se, por exemplo, a Cia. Docas de Santos, cujos sócios eram Cândido Graffée e o herdeiro Guilherme Guinle. Lineu de Paula Machado casou-se com Celina Guinle, irmã de Guilherme, e tornou-se sócio de Guilherme no Banco Boavista; Alberto Faria, sogro de Afrânio Peixoto e de Alceu Amoroso Lima, era diretor dessa companhia. Outro exemplo são as parcerias em empreendimentos urbanos na área de infraestrutura constituída por Francisco Ramos de Azevedo, Vitor da Silva Freire e Antônio Francisco de Paula Souza - colegas da Escola Politécnica de São Paulo -, que também ocuparam cargos na direção da Secretaria de Obras Públicas no estado de São Paulo. Cf. Campos, 2007. Sobre as grandes companhias de infraestrutura no Brasil, cf. Weid (1989), Campos (2007) e Lamarão (2012).

15. Sobre os "engenheiros educadores" da ABE, cf. Carvalho, 1986, e Gomes, 2015. 
ção, uma vez que suas atividades profissionais e docentes - na Escola Politécnica ou no Lyceu de Artes e Ofícios - os envolviam com a ciência aplicada. O fomento à educação francesa, nesse meio, era uma forma de distinção social.

O segundo grupo é formado principalmente por médicos ligados à Faculdade de Medicina do Rio de Janeiro e ao Hospital Nacional dos Alienados, responsáveis pelo convite a Dumas para vir ao país ${ }^{16}$. Esse grupo estava familiarizado com a produção intelectual francesa nas áreas de psicofisiologia, psiquiatria e medicina legal antes da chegada de Dumas, e alguns já haviam inclusive participado de congressos e publicado no exterior, tais como Juliano Moreira e Afrânio Peixoto. Beneficiavam-se do trabalho dos pioneiros - Nina Rodrigues, Teixeira Brandão e Franco da Rocha ${ }^{17}$ - que já haviam publicado na França e difundido no país principalmente autores franceses e italianos. Mas Juliano Moreira e Afrânio Peixoto foram além desse circuito: tinham preferência por teorias e abordagens alemãs, publicaram em inúmeras revistas internacionais e fundaram uma revista especializada em psiquiatria ${ }^{18}$. Alguns médicos desse meio se tornaram membros da Academia Brasileira de Ciências, da Academia Brasileira de Letras e da Academia Nacional de Medicina - três academias que não por acaso elegeram Dumas como membro correspondente, respectivamente, em 1916, 1922 e 1925. Apesar de manterem relações muito próximas com Dumas, não publicaram em sua revista - o Journal de Psychologie Normale et Pathologique publicou apenas oito resenhas bibliográficas e duas comunicações desse grupo entre 1906 e 1926 -, o que mostra a independência relativa de suas práticas de internacionalização ${ }^{19}$. Apenas um desses médicos estabeleceu uma parceria científica a ponto de

16. Dumas foi convidado por Maurício de Medeiros, por sugestão de Juliano Moreira, presidente da Sociedade de Psiquiatria, Neurologia e Medicina Legal. Cf. Muñoz, 2018; Melo, 2016; Cerqueira, 2014.

17. Entre 1884 e 1906, esses três autores publicaram oito textos (cinco artigos, duas resenhas e uma apresentação) nos Annales Médico-Psychologiques - a revista mais importante em psicofisiologia do período na França. Todos eles sobre doenças mentais diversas, epidemias de loucura coletivas ou instituições manicomiais no Brasil. Esse ponto é importante porque permite diferenciar a recepção dos franceses pelos "médicos-educadores" em relação à dos "educadores reformistas": os primeiros são professores do ensino superior, praticantes da medicina hospitalar, mantêm publicação em revistas de prestígio internacional e dialogam com várias escolas científicas - em particular na Alemanha e nos Estados Unidos. Cf. Muñoz, 2018.

18. Afrânio Peixoto, Juliano Moreira, Ulisses Viana, Antonio Penafiel e Raul Leitão da Cunha publicaram, entre 1907 e 1914, 5 artigos, 2 revisões e 1 comunicação nos Annales Médico-Psychologiques. Além de Afrânio Peixoto e de Juliano Moreira, destacam-se nesse grupo Maurício de Medeiros, que havia estudado com Dumas em Paris, e Miguel Ozório de Almeida. No Brasil, esse grupo fundou os Archivos Brasileiros de Psychiatria, Neurologia e Sciencias Affins, em 1905, cujo nome foi alterado para Archivos Brasileiros de Psychiatria, Neurologia e Medicina Legal, com a criação da Sociedade Brasileira de Psychiatria, Neurologia e Medicina Legal, em 1907. Cf. Facchinetti, 2010 e Muñoz, 2018.

19. As comunicações são de Medeiros e Albuquerque (1924), irmão de Maurício de Medeiros, e de 
fazer pesquisas e publicar trabalhos em coautoria com autor francês - Miguel Ozório de Almeida, que publicou artigos com Henri Piéron na França (Melo, 2016; Melo \& Campos, 2014; Souza, 2015). Provenientes de famílias menos abastadas relativamente ao grupo dos engenheiros, não deixam de fazer parte dos meios socialmente dominantes pela raridade da sua formação superior, capital intelectual que garantia a muitos ascenderem a casamentos convenientes ${ }^{20}$. Afrânio Peixoto e Miguel Ozório tornaram-se, respectivamente, reitor e vice-reitor da Universidade do Distrito Federal - o que mostra a continuidade entre esse meio e os projetos de fundação de uma universidade. Maurício de Medeiros participou da missão brasileira na França por ocasião da Primeira Guerra e assumiu inúmeros cargos públicos - na área de higiene e saúde pública. De modo geral, a atuação desses médicos esteve voltada à docência e à pesquisa (pura ou aplicada), mas também à administração pública e à política. Suas relações com Dumas e os cientistas franceses foram intensas, mas com a exceção de Piéron não se observam desdobramentos importantes para o futuro das ciências sociais no ensino superior ${ }^{21}$. No campo dos estudos médicos, Dumas possivelmente não era considerado por eles um especialista em psiquiatria - a revista de psiquiatria brasileira praticamente não publicou artigos dele - e, além disso, estavam cada vez mais interessados na produção científica alemã, que se tornava mais prestigiada do que a francesa (Munõz, 2020).

Assim, enquanto os "engenheiros-educadores" se envolveram com as missões francesas prioritariamente como mecenas ou filantropos, os "médicos-educadores" estabeleceram relações institucionais com os professores franceses. Contudo, a visão higienista ou sanitarista do social não era aquela difundida por Dumas, que pregava

Miguel Ozório de Almeida (1926) e foram feitas na Société de Psychologie - dirigida pelo grupo ligado a Dumas.

20. O caso de Afrânio Peixoto é exemplar a esse respeito. Proveniente de família abastada - seu pai era proprietário de extração de diamantes, mas entra em crise -, sua trajetória subsequente expressa escassez relativa de recursos. Ao menos é o que se deduz de sua conversa com Francisco Alves, que the aconselha a escrever um manual de educação para levantar recursos e fazer a tão sonhada viagem para a Europa. Cf. Dicionário Histórico-Biográfico das Ciências da Saúde no Brasil. Uma análise preliminar leva a identificar algumas redes de interdependência entre os meios médicos e o dos engenheiros. A família Guinle também patrocinava dois laboratórios no Rio de Janeiro: o de análises clínicas do Hospício dos Alienados, dirigido por Afrânio Peixoto, e o laboratório de fisiologia dos irmãos Miguel e Álvaro Ozório de Almeida. Ora, Afrânio é agregado da família Alberto de Faria, diretor da Cia. Docas de Santos, e Miguel e Álvaro são filhos de Gabriel Ozório de Almeida, outro diretor da Cia. Docas de Santos. Além disso, a empresa de Guinle e Graffée utilizou o espaço da Gazetta de Notícias e do OESP para seus interesses comerciais. Afrânio e Alberto de Faria são membros da Academia Brasileira de Letras. Cf. tb Sanglard 2008.

21. No laboratório de Miguel e Álvaro Ozório de Almeida trabalharam inúmeros professores franceses nos anos 1920, entre os quais Henri Piéron, Henri Laugier, Emile Gley e Louis Lapicque. Ozório de Almeida publicou dois artigos na França com Piéron. Cf. Melo, 2016. 
a colaboração entre a psicologia científica e a sociologia durkheimiana ${ }^{22}$. Um terceiro grupo, o dos "educadores reformistas" - formados em geral em direito, mas não praticantes -, que exercia o magistério nas escolas normais, onde as novas ciências do homem primeiro se enraizaram, tornou-se o principal mediador da circulação das ciências francesas no Brasil.

Desde 1912, os cursos de Dumas e, posteriormente, de outros professores franceses foram realizados na Escola Normal de São Paulo, onde estabeleceu relações sólidas com várias famílias ligadas ao PRP - entre as quais a família Mesquita - cujos filhos ali estudavam. ${ }^{23}$ Dumas tornou-se próximo da família Mesquita e de um grupo de colaboradores do jornal $O$ Estado de $S$. Paulo - envolvidos com a questão educacional pelo impacto direto ou indireto em suas atividades culturais e profissionais. A Escola Normal de São Paulo era uma instituição associada à Liga Nacionalista e à Sociedade de Educação de São Paulo - associações livres que pretendiam influenciar a agenda de reformas educacionais. Muitos dos agentes que circulavam por essas instituições eram colegas de Dumas desde 1908 - uma rede de sociabilidade que detinha todos os trunfos - sociais, políticos e intelectuais - para interferir na política educacional do estado $^{24}$. Daí a colaboração de Dumas no Correio Paulistano, entre 1909 e 1914, bem como na reforma Sampaio Dória, em 1920. Muitos deles colaboraram para a fundação do Lyceu Franco-Brasileiro de São Paulo ${ }^{25}$. Destacam-se nesse grupo, além da família

22. Pretende-se tratar conjuntamente da psicologia científica e da sociologia durkheimiana, porque foi nessa colaboração que Dumas e seu círculo investiram nos anos 1920. É importante frisar que a internacionalização da psicologia científica foi facilitada em razão de sua maior impregnação às ciências naturais. Já a sociologia durkheimiana estava associada mais fortemente à cultura francesa. Cf. Charle, 2004.

23. Em 1912, Dumas profere um curso de doze conferências na Escola Normal de São Paulo. A segunda conferência foi exatamente sobre a relação entre psicologia e pedagogia. Cf. OESP, $1^{\circ}$ de setembro de 1912. Entre os assistentes estavam membros do governo do Estado, professores da Escola Normal e os membros da União Escolar Franco-Paulista, tais como Ruy de Paula Souza, Vergueiro Steidel, Cyridião Buarque e Oscar Campelo. Cf. http://www.histedbr.fe.unicamp.br/navegando/fontes_escritas/3_Imperio/1846_escola_normal.pdf.

24. Em 1908, ocasião de sua primeira missão, Dumas visitou em São Paulo a Escola Politécnica e a Faculdade de Direito - iniciando contato com Frederico Vergueiro Steidel, Silva Telles, Silva Freire, Ramos de Azevedo, Francisco de Paula Souza, Reynaldo Porchat, Alfredo Pujol, Mendes de Almeida e Dino Bueno. Sobre a importância do OESP na vida cultural e educacional de São Paulo, cf. Miceli, 2001; Santos, 2018; Nery, 2008, e Limongi, 1989.

25. A junta pedagógica, em 1924, primeiro ano de funcionamento do Lyceu, era composta por Frederico Vergueiro Steidel (Faculdade de Direito); Prof. Rodolpho Batista S. Thiago (Escola Politécnica); Prof. Ovídio Pires de Campos (Faculdade de Medicina); Prof. J. Itapura de Miranda (Ginásio da Capital); Prof. Antônio Sampaio Doria (Escola Normal) e professor francês Drouin (agrégé). Cf. OESP, 18 de janeiro de 1924. Sampaio Dória e Frederico Vergueiro Steidel eram membros da Liga Nacionalista; Ruy de Paula Souza e Victor da Silva Freire, que patrocinaram o Lyceu, eram membros da Sociedade de Educação de São Paulo (1929). 
Mesquita, Fernando de Azevedo, Lourenço Filho, Sampaio Doria e Rui de Paula Souza. Ao longo dos anos 1920, os três primeiros foram diretores da Instrução Pública, respectivamente, no Distrito Federal, Ceará e em São Paulo, e o quarto foi diretor do Lyceu Franco-Brasileiro ${ }^{26}$. As trajetórias dos educadores reformistas se inscrevem em duas posições sociais possíveis: são membros das elites dirigentes, famílias de políticos tradicionais ou de proprietários de empresas na área de infraestrutura - caso de Rui de Paula Souza e de Fernando de Azevedo - ou membros das classes médias urbanas em ascensão pela via do capital escolar, caso de Lourenço Filho e de Sampaio Doria ${ }^{27}$. Os bem-nascidos se afastam dos negócios familiares para abraçar a carreira de educador, o que representa um salto para baixo no campo do poder - levando consigo todos os benefícios provenientes das propriedades familiares herdadas. Os providos de boa vontade cultural e de um diploma superior ascendem com a expansão do Estado na área de educação (Miceli, 2001). Algumas propriedades escolares distinguem esse grupo: três se formaram pela Faculdade de Direito do Largo São Francisco - onde conheceram alguns dos fundadores da União Escolar Franco-Paulista, tais como Reynaldo Porchat e Frederico Steidel -, e todos foram professores ou diretores da Escola Normal de São Paulo. Quanto à área do magistério, tornaram-se professores de psicologia e pedagogia (Doria e Lourenço Filho), psicologia e latim (Fernando de Azevedo e Lourenço Filho) e letras modernas - francês (Paula Souza) ${ }^{28}$. Através de uma formação híbrida, letras clássicas e ciências modernas, adquiriram possivelmente as disposições necessárias para simpatizar com seus homólogos franceses e suas proposições sobre as ciências do homem.

Comparando-se as propriedades sociais e intelectuais dos educadores reformistas com a dos professores franceses, conclui-se que os primeiros ocupavam posição

26. O projeto de fundação de um liceu em São Paulo data de 1916, e Dumas inicialmente pensou em construir quatro liceus no Brasil. Cf. Kovacevic, 2019, pp. 53-54. O patrimônio inicial foi doado pelo Parlamento, e outra parcela veio dos bancos, companhias francesas e casas com interesses no Brasil. Por falta de recursos, foi necessário procurar patronos no Brasil e dividir a administração do Lyceu concedidos pelo governo de São Paulo, governo federal e patronos privados.

27. As famílias de Ruy de Paula Souza e de Fernando de Azevedo eram, respectivamente, proprietárias do setor de infraestrutura urbana - ferrovia ( $\mathrm{SP}$ ) e transportes (RJ). Suas famílias provavelmente mantinham relações, pois Francisco de Paula Souza era sócio da Estação Sorocabana, e Francisco Eugênio de Azevedo era sócio da Companhia Ferro-Carril Guarany. Após um período de instabilidade econômica familiar, Fernando de Azevedo contrai casamento aos 23 anos com Elisa Assumpção do Amarante Cruz, filha do médico do exército e acionista do Banco União de S. Paulo, Luiz Gonzaga do Amante Cruz. O pai de Lourenço Filho era pequeno comerciante, e o de Sampaio Doria havia sido major do exército imperial. Ambos lecionaram durante o período de formação. Cf. Miceli, 2001.

28. Exceção feita a Ruy de Paula Souza - que fez toda sua formação em Paris - e obteve a licença em Letras pela Sorbonne. No Brasil, cursou a Escola de Minas de Ouro Preto. Paula Souza, ao contrário dos demais, era da mesma geração que Dumas e talvez tenha entrado em relações com ele quando aluno em Paris. 
socialmente dominante em relação à dos franceses e, por sua vez, no que diz respeito ao seu capital cultural específico, eram dominados, porque o conjunto de títulos dos franceses representava uma barreira intransponível mesmo para as famílias abastadas brasileiras. Apesar de ocuparem posições opostas do ponto de vista social e intelectual, existe uma homologia de posição entre eles: os professores franceses ocupam posição dominada nas hierarquias disciplinares, assim como os educadores brasileiros no campo do poder. Assim, a recepção favorável às ciências do homem francesas pode ser tributada à homologia de posição que possibilita eleições mútuas. Para a fração das elites dirigentes com funções educacionais, em particular os "educadores reformistas" de São Paulo, as missões francesas permitiram legitimar novas práticas (científicas, educacionais, editoriais, administrativas) diante dos chamados "diletantes" e dos políticos "puros" (Limongi, 1989).

\section{Os professores franceses na imprensa paulista: cursos e conferências}

Os cursos e as conferências de Dumas no Brasil foram publicados nos jornais de São Paulo desde o início das missões científicas, em 1908. O volume dessas publicações permite inferir o enorme investimento do professor francês na difusão da filosofia e das ciências do homem francesas, bem como a familiaridade dos leitores com seus textos após anos de colaboração ${ }^{29}$. Essa é uma dimensão da circulação das ideias em geral pouco considerada pelos estudiosos, em razão da dificuldade de acesso aos registros, mas foi fundamental como estratégia para familiarizar o leitor com autores e obras estrangeiras, bem como com questões educacionais internacionais. Entre 1908 e 1918, as contribuiçóes de Dumas foram mais literárias e pitorescas, enquanto no período seguinte, após a Primeira Guerra, tornaram-se mais sérias e científicas.

Desde os primeiros cursos, observa-se que Dumas abraça a política cultural do Estado francês ao promover a sociologia durkheimiana e a psicologia científica francesa, bem como o modelo de educação francês. $O$ curso ministrado por ele na Escola Normal de São Paulo, em 1912, contou com diversas aulas sobre psicologia e pedagogia, bem como sobre as reformas educacionais na França. Nos anos 1920, os cursos sobre as reformas do ensino e as ciências do homem na França foram ainda mais frequentes, pois caíam sob medida na agenda política dos meios intelectuais paulistas. Os cursos presenciais, publicados no jornal O Estado de S. Paulo, deram

29. Entre 1909 e 1914, Dumas foi colunista do Correio Paulistano e escreveu em torno de duzentas colunas nesse período. É importante frisar que, nas reportagens sobre as missões francesas, os jornais exaltavam Dumas como o "Einstein da Sorbonne" e o "amigo do Brasil" - deslumbramento que não se encontra entre seu círculo mais próximo. 
origem à coluna mensal de Dumas e, alguns anos depois, de Paul Fauconnet, sociólogo e professor da Sorbonne. Dumas e Fauconnet escreveram aproximadamente cinquenta colunas cada um para o OESP ao longo dessa década ${ }^{30}$. Além disso, os professores franceses realizaram inúmeras atividades no país: publicaram obras e prefácios; orientaram colegas e assessoraram reformas; elaboraram o projeto do Lyceu Franco-Brasileiro de São Paulo e das universidades nos anos 1930; finalmente, indicaram professores franceses para ocupar cátedras. Suas atividades se dirigiam tanto a um público amplo, a elite cultivada, quanto a um público restrito de educadores e professores do ensino superior. Um investimento intenso e diversificado, feito coletivamente, que indica que a legitimação das novas ciências humanas no Brasil não era algo espontâneo ou natural, fruto direto das afinidades linguísticas e do estilo de vida de uma elite afrancesada.

O diálogo entre os professores franceses e os educadores brasileiros foi facilitado pelo processo, ocorrido simultaneamente nos dois países, de institucionalização das novas ciências humanas nas escolas normais primárias. Na França, após a institucionalização dessas ciências nas universidades, tratava-se de investir na difusão científica para fins de formação cívica e/ou de cultura científica. Iniciada com a reforma de 1920, a expansão instituiu sociologia na grade curricular das escolas normais primárias, gerando com isso demanda por novos manuais escolares e dinamizando o polo pedagógico do campo editorial - até então dominado pela história e pela filosofia. Os manuais de sociologia foram publicados ou por durkheimianos estritos ou por antidurkheimianos inspirados na psicologia social francesa (Geiger, 1979; Terral 2005, 2008; Savoye, 2007). No ensino secundário, a disputa se dava entre os defensores do ensino de humanidades clássicas e os de ciências modernas, ou melhor, entre uma visão nacionalista - que opunha as humanidades francesas às ciências alemãs - e uma visão modernista do ensino. Assim, o debate entre filósofos e sociólogos, que recobriu até certo ponto o embate entre católicos e laicistas, foi o mote que orientou coleções e reformas nessa década (Geiger, 1979, Savoye, 2007).

Os manuais franceses foram muito difundidos fora da França. No Brasil, pode-se identificá-los nas referências bibliográficas das obras de psicologia e de sociologia dos anos 1920 e 1930 - como os de Hesse e Gleyse (1920) e de Bouglé e Raffard (1926). Ao mesmo tempo, as reformas francesas também foram amplamente comentadas e debatidas por aqui - a ponto de se constituírem no campo ideológico tomadas de posição pró ou contra determinados autores e reformas na França. Assim, os grupos e os argumentos utilizados na própria França contra a sociologia durkheimiana e

30. Dumas deu início à colaboração em 1923 e encerrou em 1930 - ausentando-se em 1924 e 1925, quando foi substituído por Albert Thibaudet. Fauconnet deu início à colaboração em 1927 e encerrou em 1930. 
a psicologia científica eram mobilizados nas disputas locais. Apesar das enormes diferenças entre o sistema de ensino na França e no Brasil, a institucionalização das ciências do homem nas escolas normais era o caminho possível para sua institucionalização nas universidades do futuro - processo inverso ao que ocorreu na França ${ }^{31}$.

As conferências e colunas de Dumas do período indicam quais eram as causas prioritárias na área de educação: a "Escola Única” como antídoto à "luta de classes" escolar ${ }^{32}$; o ensino secundário orientado pelo "desinteresse" e voltado à "cultura do espírito" contra o ensino "útil" e "profissional"; o papel central das faculdades de letras e de ciências na universidade, cujos propósitos seriam formar consumidores e produtores em ciência e em cultura, bem como docentes para o ensino secundário e superior ${ }^{33}$. Dumas, contudo, não ousava defender que o Brasil copiasse as instituições francesas - o que significaria constranger o espírito nacionalista das elites dirigentes; investia na invenção de uma tradição comum, a dos países "latinos”, cujo propósito seria preservar sua "tradição cultural” em oposição às nações com "poder econômico" 34 . Inspirava-se na antiga oposição entre povos latinos e anglo-saxônicos,

31. Esse processo não foi realizado sem tensões e soluções negociadas com as escolas confessionais francesas no Brasil. Os professores franceses tiveram que adotar uma posição na França e outra no Brasil: na França, defendiam a lei de 1905 da separação entre Igreja e Estado; no Brasil, apoiaram as escolas francesas confessionais. Cf. Suppo, 2001.

32. O movimento pela Escola Única na França não deve ser confundido com o movimento pela Escola Nova - de âmbito internacional. Aquele movimento defendia a supressão do curso primário nos liceus para que todos os alunos da escola pública ingressassem no sistema pelas escolas primárias. Nesse período, os alunos do liceu - originários das classes abastadas - cursavam o primário no próprio liceu, enquanto as classes populares cursavam a escola primária e primária superior, gerando uma separação entre classes sociais. Cf. Dumas, OESP, 19 de agosto de 1928.

33. A sugestão de Dumas também incluía a criação de faculdades de educação, nos moldes da Escola Normal Superior francesa. Veja-se a esse respeito a menção à participação de Dumas na reforma das escolas normais de São Paulo feita por Sampaio Doria: “Em 1920, nas reuniões promovidas pelo professor Sampaio Doria na Diretoria Geral do Ensino, vós, senhor professor George [sic] Dumas, esforçando-vos, segundo a vossa maneira fidalga, por figurar como simples colaborador secundário, trazíeis precioso contingente para o plano da Faculdade de Educação, escola superior destinada ao aperfeiçoamento pedagógico dos professores e à disseminação da cultura geral. A Faculdade de Educação, embora chegasse a ser criada por lei do Estado, não passou do papel. Mas a semente ficou”. Almeida Júnior, sessão especial de nomeação de Dumas doutor honoris causa na USP - 11 de junho de 1937. Cf. Anuário da USP, 1938. Tudo indica que, como o projeto não foi adiante, Dumas tenha alertado que uma faculdade de educação com orientação "estritamente prática" poderia prejudicar a fundação de uma faculdade de letras.

34. A invenção de uma tradição na América Latina como região de alta cultura faz parte da retórica de quase todos os professores franceses desse período. "A América Latina, região de velha cultura, compreende que, para ser mais forte, para firmar a sua personalidade, só lhe resta organizar a sua própria força, ser latina no sentido mais completo do termo, e é por isso que [...] todas as nações que visitei aperfeiçoam o seu ensino secundário para recrutar mais amplamente as suas elites, reforçar o seu espírito nacional, valorizar todas as duas riquezas intelectuais e também preparar chefes para a luta econômica em que estão empenhadas. A América Latina com o aperfeiçoamento do seu ensino secundário 
retórica ensaística do fim do século XIX, a fim de enfatizar a distância entre América Latina e América Anglo-Saxônica.

Por sua vez, as conferências e colunas de Fauconnet foram quase todas dedicadas ao tema da educação e tinham um viés mais especializado, uma vez que ele ocupava na Sorbonne a cadeira de Ciência da Educação ${ }^{35}$. Assim como Dumas, ele defendeu o movimento reformista francês denominado "Escola Única", ou seja, a obrigatoriedade da escola primária para todos os alunos do ensino público, com vistas a combater a desigualdade gerada pelo sistema escolar francês. Defendeu igualmente o movimento escolanovista à medida que promove os estudos científicos, biológicos e psicológicos sobre a criança e o adolescente, mas reivindicou papel central à sociologia - tanto na formação docente quanto na definição de políticas públicas na área de educação. Como a educação é um fato social, afirmava, caberia à sociologia estabelecer os "fins" do ensino de acordo com cada civilização ou país. Além disso, via com desconfiança a celebração da "autonomia" e da "liberdade" da criança, à qual se referia como baseada em "falsa ciência", ainda que identificasse em tal clamor um aspecto positivo - a moderação das tendências autoritárias do ensino tradicional. Finalmente, não considerava adequada a orientação pragmática da pedagogia escolanovista - principalmente quando aplicada aos níveis mais avançados de escolarização ${ }^{36}$. O professor, defendia, é um representante da sociedade em sala de aula e a ele cabe a formação do indivíduo segundo o determinado por cada sociedade - uma concepção de autoridade estranha ao espontaneísmo escolanovista norte-americano. Assim, ao hierarquizar dois modelos de ensino e duas ciências, a sociologia e a psicologia, Fauconnet coloca em oposição duas civilizações, a francesa e a estadunidense $e^{37}$. Essa oposição se exacerba quando ele discute o ensino secundário: o modelo francês é o melhor, pois se baseia no "desinteresse" em oposição ao "útil" e ao "profissional", cuja função deve ser a formação de uma "cultura geral”. Contudo, admite, a cultura do espírito pode ser atingida tanto pelas humanidades clássicas (grego-latim) quanto pelas humanidades modernas (língua e literatura modernas e ciências), ainda que na França ele se colocasse do lado modernista.

não tem de criar um capital intelectual, mas obter um rendimento metódico do capital que a maioria das nações que a constituem possuem há muito tempo - algumas há vários séculos." Dumas, OESP, 17 de novembro de 1928. Veja-se também artigo de Dumas de 25 de agosto de 1927.

35. Fauconnet foi presidente do "Grupo francês" da Liga Internacional pela Educação Nova, fundada em 1921, e Henri Piéron foi vice-presidente.

36. Sobre a recepção do ideário francês e estadunidense nos meios escolanovistas, cf. Bomeny, 2001, p. 45, e Nascimento, 2012, p. 94 . O movimento pela Escola Única na França era distinto do movimento escolanovista, mas ambos propunham democratizar o acesso ao ensino, racionalizar a seleção de alunos, modernizar a formação docente e institucionalizar a psicologia e a sociologia em todos os níveis de ensino.

37. Entre as diversas vertentes da Escola Nova, ele dá maior atenção à concepção suíça da "escola ativa”. 
Esses debates tinham impacto direto nas reformas brasileiras e claramente visavam a atender uma demanda local. O Lyceu Franco-Brasileiro havia sido construído em bases “clássicas", e Fauconnet teve de fazer um contorcionismo: na França, país cujo ensino secundário era tradicionalista, seria bom expandir o ensino moderno; nos países novos, como o Brasil, poder-se-ia dar ênfase ao ensino clássico ${ }^{38}$. Também se observa o atendimento à demanda local quando Fauconnet trata do ensino superior: as escolas normais primária e secundária deveriam ser fundidas e, ao mesmo tempo, deveriam abrigar uma instituição de formação cultural e científica superior, ou seja, uma faculdade de educação. Sem um ensino superior, não seria possível formar docentes para o ensino secundário. Além disso, deveria haver equiparação material e simbólica entre a carreira do professor secundário e a do universitário - além da liberdade de cátedra, dedicação exclusiva e pesquisa. Finalmente, as universidades deveriam ter jurisdição estadual e não federal ${ }^{39}$. Assim, observa-se um processo de adaptação constante, mais ou menos consciente, entre as demandas de parcela dos educadores locais e as preferências dos professores franceses.

No contexto da circulação internacional das ciências do homem, a difusão da sociologia durkheimiana tinha várias funções: questionar a concepção escolanovista estadunidense em nome da visão francesa - mais dirigista e intelectualista - e combater a psicologia social norte-americana em nome da sociologia francesa. Assim, entende-se que Dumas e Fauconnet publicassem tantas colunas no jornal sobre sociologia durkheimiana e que Fauconnet tenha escrito o prefácio de Educação e Sociologia (1929) - a primeira obra de Durkheim a ser traduzida no Brasil. A difusão de um Durkheim "pedagogo" e "cientista" atacava essas duas frentes. No livro Educação e Sociologia, Durkheim confrontava "espontaneístas" e "individualistas" em matéria educacional ${ }^{40}$. Sem negar o trabalho dos educadores sobre a estrutura biológica e psicológica dos indivíduos, Fauconnet reforçava a visão durkheimiana: a sociologia ultrapassava os condicionantes fisiológicos ou psicológicos dos indivíduos

38. “A questão das humanidades não se apresenta nos mesmos termos para todos os países e para toda época. Pode haver aqui um excesso e ali deficiência. Sem contradição, posso ao mesmo tempo pedir que se modere, na França, um regime muito exclusivo de humanidades e que alhures, no Brasil, por exemplo, se lhe abra um lugar mais amplo." Fauconnet, OESP, 9/5/1928.

39. São inúmeras as sugestôes de Fauconnet e impressiona a maneira direta como orientou seu público leitor - em São Paulo e no restante do país, considerando-se que em 1930 a tiragem diária do OESP era aproximadamente de 100 mil exemplares. Defendeu que o Conselho Universitário incorporasse membros da sociedade civil, além de estrangeiros, e que os professores atuassem de maneira mais ativa na sociedade, tornando-se formadores da opinião pública. Essas orientações eram em parte reflexo do momento altamente politizado da universidade francesa no período entreguerras. Fauconnet, OESP, $12 / 10 / 1927$.

40. Ao defender a ideia de que a educação varia segundo a estrutura social de um país, o autor afastava-se necessariamente da base naturalista e psicologizante dos escolanovistas. Cf. Durkheim, 1929. 
e, mais do que isso, dava conta de tais condicionantes. Essas ciências poderiam se complementar, mas nunca substituir umas às outras ${ }^{41}$.

Henri Piéron também esteve no Brasil por duas vezes ao longo dos anos 1920. Era professor do Collège de France, chefe do laboratório de psicologia fisiológica da Sorbonne e diretor de L'Année Psychologique. Especialista em psicologia experimental e psicologia aplicada à educação e ao trabalho, foi um importante colaborador do Traitéde Psychologie de Dumas - muito usado pelos educadores brasileiros. Contudo, na própria França, a psicologia experimental e aplicada ocupava posição dominada em relação à psicologia filosófica. Assim, dedicara uma parte de seu tempo às missões possivelmente porque, além do dever cívico, era preciso buscar algum reconhecimento no exterior. Suas publicações o habilitavam a atender as demandas dos médicos e a dos educadores: com Miguel Ozório de Almeida, professor da Faculdade de Medicina do Rio de Janeiro, realiza pesquisas conjuntas e publica artigos em coautoria na França; no caso de Lourenço Filho, professor da Escola Normal, a relação é entre mestre e discípulo e ele se torna orientador de suas pesquisas e escritos ${ }^{42}$. Piéron não escreveu no $O E S P$, como Dumas e Fauconnet, possivelmente em razão do caráter biológico e especializado de sua produção intelectual, mas suas aulas foram publicadas em livro pela coleção da Escola Normal de São Paulo, além de ter um livro traduzido pela coleção de Lourenço Filho: esses textos tratavam de psicotécnica e de psicologia da educação (Piéron 1927a, 1927b). No caso da psicologia aplicada, Piéron defendia o estudo das "atitudes" do indivíduo (aptidões), abordagem que se opunha, até certo ponto, àquela utilizada nos testes de "QI" de mensuração da inteligência pela psicologia norte-americana ${ }^{43}$. Suas críticas, entretanto, eram de nuance, ainda que exaltasse os pioneiros franceses - Alfred Binet e Théodore Simon - em todas as descobertas posteriores dos norte-americanos. Piéron obteve reconhecimento no país - foi eleito membro correspondente da Academia Brasileira de Ciências e da Academia Nacional de Medicina, como Dumas e, em retribuição, apoiou a candidatura de vários colegas brasileiros a correspondente estrangeiro em diversas sociedades científicas francesas. Assim, essas nomeações eram expressões de reconhecimento

41. "Porque a psicologia é evidentemente incompetente quando se trata de dizer não o que seja a criança, que recebe a educação, sua maneira própria de assimilar e de reagir, mas a natureza mesma da civilização que a educação transmite e a aparelhagem que ela emprega para transmiti-la.” Fauconnet, 1929, pp. 12-13.

42. As cartas de ambos a Henri Piéron são reveladoras nesse sentido. Cf. Piéron. Institut de Psychologie. Université Paris Descartes, Fundo Piéron. Cf. Souza, 2015; Melo, 2016.

43. É importante notar que as disciplinas "experimentais" e "aplicadas" possuíam maior potencial de circulação por sua maior autonomia em relação à cultura de origem ou ao campo de produção. Em um contexto nacionalista, como o dos anos 1920, a sociologia durkheimiana levava desvantagem por sua associação à cultura francesa (que podia ser lida como "imperialista") em comparação à psicologia experimental, cujo fundamento naturalista podia ser apreciado como "universal". 
mútuo e complementavam o trabalho simbólico das missões. Nesse sentido, as trocas estabelecidas pelos cientistas nas missões dos anos 1920 contribuíram para a pesquisa dos estudiosos brasileiros e podem ser tratadas também como expedições científicas, sem prejuízo de seu caráter diplomático (Petitjean, 1989). Elas são fruto dos interesses associados às trajetórias de ambos os grupos.

\section{Das humanidades clássicas às humanidades modernas}

A circulação das ciências do homem francesas, conforme mencionado, foi mais ampla entre os educadores reformistas de São Paulo, pois foi com eles que os franceses realizaram um intenso trabalho intelectual e institucional - atuando nas reformas do ensino, na Escola Normal de São Paulo, no Lyceu Franco-Brasileiro e em coleções editoriais coordenadas por esse grupo. O enraizamento local de teorias educacionais e de categorias científicas francesas permitiu a esses educadores legitimarem-se tanto diante das elites dirigentes paulistas quanto dos educadores concorrentes num momento de concentração crescente das funções educacionais pelo Estado. Esses alguns dos condicionantes das mudanças que se observam nas preferências dos educadores de São Paulo nos últimos anos da década de 1920 e que levam os educadores a abraçar a "ciência francesa".

Os anos 1920 no Brasil se caracterizam por inúmeras transformações na educação: reformas no sistema educacional, institucionalização de novas cadeiras nas escolas normais e no secundário, publicação de novos manuais escolares, realização de concursos etc. Esse conjunto de práticas era a um só tempo resultado e promotor do movimento escolanovista que, grosso modo, pode ser caracterizado por três características principais: pedagogia centrada no aluno, estudo científico da criança e do adolescente e escolas experimentais. $\mathrm{O}$ movimento contribuía para a legitimidade das novas ciências do homem porque a formação de professores passava a se basear na biologia, psicologia e sociologia da educação. Para os educadores reformistas, era fundamental defender as ciências da educação porque elas permitiam levantar uma barreira contra os professores chamados "diletantes" ou "autodidatas" - muitos deles nomeados por indicação política ${ }^{44}$. Contudo, as referências bibliográficas utilizadas nos manuais brasileiros eram predominantemente estadunidenses e, quando europeias, mencionavam autores suíços, italianos, alemães e russos. Assim, os professores franceses enfrentavam um movimento de opinião pedagógica muito adverso externamente ao círculo restrito do $O E S P$ - em particular no que diz respeito à sociologia 
durkheimiana, cujo diálogo com o escolanovismo era tenso -, de modo que as bases científicas do movimento escolanovista estavam longe de um consenso (Vidal, 2013).

Nesse sentido, a preferência pelo modelo de educação e pelas ciências do homem francesas ou europeias não foi algo espontâneo. No círculo do $O E S P$, as trajetórias escolares e docentes indicam duas instituições principais como fonte de sua formação. No Largo São Francisco, incutiam-se uma cultura literária e o engajamento político - disposições contrárias ao durkheimismo estrito; na Escola Normal de São Paulo, a cultura científica era mais valorizada - ainda mais na área de psicologia, em razão de seu laboratório -, mas as práticas e concepções pedagógicas eram predominantemente norte-americanas (Warde, 2003). Fernando de Azevedo e Lourenço Filho merecem destaque no círculo paulista porque são os principais agentes da transição entre esses dois mundos e as ciências do homem francesas. Fernando de Azevedo ensaísta, classicista e crítico literário no início de sua vida intelectual - foi o autor que mais se apropriou do referencial sociológico durkheimiano (Nascimento, 2012). Seu contato com o durkheimismo se deu possivelmente com a mudança para São Paulo, em 1919, momento a partir do qual ingressa na Escola Normal de São Paulo, conhece Lourenço Filho e passa a colaborar no jornal OESP. Em 1921, ele já está presente na reunião que celebra o projeto do futuro Lyceu Franco-Brasileiro de São Paulo. Como diretor da Instrução Pública no Distrito Federal, entre 1927 e 1930, institui concurso para professor da Escola Normal do Distrito Federal e funda uma cadeira de sociologia. Em 1931 ele é convidado por Lourenço Filho a lecionar sociologia na Escola Normal de São Paulo e, em 1933, institui a cadeira de sociologia em todas as Escolas Normais de São Paulo (Vidal, 2013, Vidal et al., 2020). Lourenço Filho se tornou um grande admirador da psicologia científica francesa apesar de, como ele mesmo afirmou, ter sido um adepto da psicologia norte-americana desde os tempos da Escola Normal de Piracicaba (Lourenço Filho, 1956). Sua vinda para a Escola Normal de São Paulo, no início dos anos 1920, onde ocupa a cadeira de Psicologia e Pedagogia, permite a reativação do laboratório de psicologia experimental, onde ocorrem os cursos dos professores franceses (Monarcha, 2001; 2009). Em 1924, publica uma resenha elogiosa do Traité de Psychologie de Dumas - que defendia a psicologia fisiológica e patológica francesas, bem como uma colaboração com a sociologia durkheimiana (Consolim, 2018). Entre o ponto de partida e o de chegada dessas trajetórias, houve dois marcos intelectuais importantes envolvendo as missões francesas: a fundação do Lyceu e de uma coleção editorial.

A fundação do Lyceu Franco-Brasileiro de São Paulo organizou as relações entre os educadores do OESP e os professores franceses em torno de um projeto educacional (Suppo, 1999; Vercesi, 2010; Kovacevic, 2019). Conforme os liceus da França, o modelo de ensino baseava-se no "desinteresse" e na "cultura geral", ou seja, seu 
propósito era a formação do espírito sem a preocupação com o ingresso no ensino superior - demarcando-se assim tanto das funções do ensino primário quanto das faculdades profissionais. Esse era um aspecto central do sistema de ensino francês, cuja implantação no Brasil não era algo simples por motivos institucionais e profissionais, mas também por razões políticas e ideológicas, pois estava associado ao "estrangeirismo" e ao "elitismo" ${ }^{45}$. O grupo do OESP encampou o projeto do Lyceu, mas foram necessárias restrições ao projeto original devido ao que Mesquita Filho denominou "nacionalismo exacerbado" do sistema educacional brasileiro (Pontes, 2010, p. 153; Vercesi, 2010, p. 83). O governo federal concedeu aos franceses apenas as matérias de "humanidades clássicas" (latim e grego), modernas (língua e literatura francesa) e filosofia - além do método de ensino (Vercesi, 2010; Medeiros, 2005). Esse modelo de formação dava acesso na França às grandes escolas ou às universidades, mas no Brasil gerou celeuma sobre sua função.

Os embates sobre o ensino de "humanidades clássicas" ocorreram nas associações educacionais e nas instituições de ensino - com ampla difusão pelos jornais da época (Nery, 2008; Carvalho, 1986). Um círculo intelectual importante, formado por membros da direção da Associação Brasileira de Educação, em sua seção carioca, tinha outra visão sobre o que deveria ser o ensino secundário ${ }^{46}$. Eram adeptos do ensino utilitário e profissional e, por isso, inspiravam-se em Gustave Le Bon, autor que criticara o sistema educacional francês e, em particular, o ensino do latim e do grego - que ele associava à psicologia decadente dos "povos latinos" adoradores de "quinquilharia inútil" ${ }^{77}$. Le Bon era um grande admirador do ensino estadunidense e daí sua importância para a $\mathrm{ABE}$ carioca. A visão pragmática do ensino associava-se na ABE carioca a certo modelo de ciências do homem: o modelo estadunidense ${ }^{48}$. Em

45. O ensino secundário no período estava subordinado ao ensino superior e se restringia à preparação para as faculdades profissionais - portanto, não tinha uma identidade própria. $\mathrm{O}$ fato de não haver formação superior especializada nas áreas literárias, ou seja, professores dedicados ao secundário, eternizava o sistema. Cf. Nagle, 2006, p. 303, e Nagle, 2009.

46. O Liceu Francês do Rio de Janeiro não enfrentou os mesmos problemas, pois não estava estruturado segundo o modelo dos liceus franceses, ou seja, não oferecia o ensino de humanidades clássicas.

47. Le Bon talvez tenha sido o autor mais prejudicial aos objetivos educacionais das missões francesas. Portador de uma trajetória outsider ao campo universitário, tornara-se um detrator da França e das "raças latinas". Era um ensaísta defensor do liberalismo econômico, da educação privada e dos povos “anglo-saxônicos”. Sua Psychologie de l'Éducation (1902) defendia uma educação profissional voltada ao sucesso individual. "A escola europeia representa o mais grosseiro desconhecimento da natureza infantil e humana. Molda os cérebros sem pudor ou vergonha; suprime a originalidade e nivela as personalidades como uma máquina equalizadora. A escola americana exalta a individualidade, libera-a para manifestar suas qualidades próprias [...] conservando a liberdade de apreciação, discernimento, originalidade e responsabilidade." Le Bon, 1902, p. 74. Cf. Consolim, 2008; Carvalho 1987.

48. Em uma das propostas sobre o ensino de sociologia, difundidas pela comissão do ensino secundário, sugeria-se um curso visando ao preparo para a "vida prática" e recomendava-se enfatizar a "ciência apli- 
defesa das humanidades clássicas estavam os “amigos de Dumas”, tais como Victor da Silva Freire, Franco da Rocha, Ruy de Paula Souza, Fernando de Azevedo e a família Mesquita - todos membros da Sociedade de Educação de São Paulo. Segundo eles, era fundamental o ensino dessas matérias para a formação das elites dirigentes. Assim, defendiam a cultura geral pelo emprego de termos tais como "formação", "espírito" e "desinteresse" a fim de combater a concepção instrumental do ensino associada aos termos "instrução", "prático" e "utilitário”9. Em 1924, o professor de um liceu francês, Marcel Drouin, proferia conferência na Sociedade de Educação de São Paulo na qual defendia uma formação "humanística” para a "elite" contra os defensores do ensino "útil” e "profissional” (Nery, 2008, p. 37).

As concepções do grupo de educadores de São Paulo foram sintetizadas no Inquérito do OESP de 1926 (Azevedo, 1960). O ensino secundário deveria promover um curso de "cultura geral (não enciclopédico)", "integral", "sem preocupações profissionais", "não especializado" para a formação das "classes médias" - em oposição à orientação norte-americana, que valorizava o ensino pelo seu "grau de utilidade imediata" para as massas ${ }^{50}$. O modelo proposto é claramente definido a partir da oposição entre Europa e Estados Unidos, entre “industrialismo" e "cultura” - conforme a oposição entre poder econômico e poder cultural desenhada por Dumas ${ }^{51}$. Essas referências estavam fundadas na ideologia da latinidade: as "humanidades clássicas" eram a marca da nacionalidade francesa contra a "ciência alemâ", assim como a marca da América Latina contra o industrialismo norte-americano. Em nome dessa oposi-

cada”. Na lista de tópicos e de referências bibliográficas, identifica-se a orientação psicologizante e individualista, bem como voltado aos "problemas sociais" do tempo presente. A psicologia social e as leis da imitação são tópicos gerais que introduzem o curso. Após a menção a autores estadunidenses e alemães, mencionam-se Durkheim e Lévy-Bruhl. Defende-se aí a necessidade de uma "Sociologia Geral", pois a sociologia ainda não é suficientemente científica. Enfatiza-se a dimensão aplicada da sociologia. Cf. "Programa de Sociologia. Programa Secundário - bases para uma reforma", apud Carvalho, p. 147.

49. "O que diferencia o ensino americano do ensino francês baseia-se exatamente nessa distinção substancial: aqueles tendem ao método da autoridade, da estatística ou das fórmulas científicas (caráter informativo), enquanto este visa antes ao aproveitamento da "capacidade formativa" de cada matéria para despertar e desenvolver o espírito de análise, o sentido de observação, a curiosidade intelectual e a penetração psicológica. Ruy de Paula Souza. “Liceu Franco-Brasileiro”. OESP, 10 mar. 1925.

50. "O exame é ainda, na instrução, o único ídolo a que o aluno e a família, solidários, fazem grandes sacrifícios... Mas aqui como nos outros países americanos, já se desenha, com toda nitidez, a reação salutar contra a superstição da utilidade a todo transe, que erigiu à categoria de ideal, na organização e no funcionamento do ensino secundário, a rapidez em concluí-lo com o menor esforço possível." Azevedo, 1960, p. 263.

51. Assim, a solução para o ensino secundário é uma combinação "eclética” entre humanidades clássicas, ciências e língua e literatura modernas. O ensino deveria ter as seguintes funções: a formação do espírito (língua, literatura e ciências), a formação da consciência nacional (língua e literatura nacional, história e geografia nacional) e universal (história da civilização, geografia geral, filosofia ou história do pensamento). Cf. Azevedo, [1926] 1960, p. 265. 
ção, Azevedo refere-se positivamente à reforma de Bérard na França, de 1923, que instituíra a obrigatoriedade das humanidades clássicas no secundário, mas também suprimira a sociologia das escolas normais primárias ${ }^{52}$. A defesa da obrigatoriedade das humanidades clássicas por esse grupo impeliu os professores franceses, adversários de Bérard na França, a adaptarem suas tomadas de posição ao contexto brasileiro ${ }^{53}$.

Mas essa crença coletiva estava prestes a perder parte de seus defensores. Pois só fazia sentido enquanto os educadores do círculo de São Paulo se identificassem com o grupo socialmente dominante no campo do poder - os patronos do Lyceu. Em outras palavras, enquanto os laços que os vinculavam às famílias proprietárias fossem mais fortes do que os que os constituíam como educadores, ou seja, como dominados no campo do poder. Por algum tempo, as preferências dessas famílias proprietárias, formadas pelos engenheiros, médicos e juristas amigos de Dumas, impuseram-se inconscientemente aos educadores. A fundação do Lyceu Rio Branco com a colaboração de Sampaio Doria e de Lourenço Filho - não por acaso socialmente dominados em relação a Fernando de Azevedo e a Ruy de Paula Souza - indicava que os educadores ligados à Escola Normal de São Paulo se distanciavam do projeto do Lyceu Franco-Brasileiro em razão de seus ares aristocráticos (Medeiros, 2005; Vercesi, 2010; Kovacevic, 2019). Alguns anos mais tarde, no Manifesto dos Pioneiros (Azevedo et al., [1932] 2010), exprime-se a ruptura: os educadores não mencionam a formação em "humanidades clássicas" como necessária à cultura geral, mas apenas em "humanidades modernas" (língua e literatura moderna), o que revela um deslocamento e uma demarcação em relação aos interesses das elites políticas dominantes em nome de interesses propriamente educacionais - em consonância com as orientações de Piéron e de Fauconnet ${ }^{54}$. Fernando de Azevedo abandonara seus escritos literários para aderir ao durkheimismo estrito. Lourenço Filho se distanciara do modelo norte-americano para aderir à psicologia científica francesa - o que se explicita na correspondência com Piéron ${ }^{55}$. As mudanças observadas nas tomadas

52. Bergson está ao lado de Bérard contra os durkheimianos e, portanto, contra os professores franceses em missão no Brasil. Em geral, os antidurkheimianos, incluindo os católicos, são adeptos de Bergson. Cf. carta de Bergson a Bouglé. Cf. Bergson, Bérard \& Besnard, 1979.

53. Dumas, "As ideias do sr. Henri Bergson sobre o ensino secundário”. oEsP, 8 jul. 1923.

54. As assinaturas do Manifesto indicam uma aproximação entre os educadores do Rio de Janeiro e de São Paulo. Isso porque Fernando de Azevedo, em sua gestão no Distrito Federal, aproximou-se de alguns membros da ABE carioca, tais como Francisco Venâncio Filho e Edgar Sussekind, signatários do Manifesto (Carvalho, 1987). Nota-se, contudo, a ausência de dois nomes importantes da educação da época: Antônio Carneiro Leão e Gilberto Freyre - o que provavelmente se deve às disputas no terreno próprio da sociologia entre as vertentes francesas e norte-americana.

55. Carta de Lourenço Filho a Piéron: "Como sul-americano, mais próximo da cultura francesa, fico um pouco decepcionado com tudo o que vejo e ouço. As tendências dos praticantes da psicologia me pareceram muito estreitas, analíticas e fragmentadas. Falta espírito de síntese ou, se o senhor me permite, 
de posição de ambos os autores ocorreram no mesmo período em que estavam à frente de um projeto editorial realizado em parceria com os professores franceses.

\section{A Coleção Bibliotheca de Educação e a circulação do escolanovismo}

Nos anos 1920, os educadores reformistas também investiram em coleções editoriais na área das ciências da educação - uma das estratégias para marcar posição na disputa entre preferências e referências estrangeiras. Alguns estudos já mencionaram a relação entre a circulação internacional e as primeiras coleções na área de educação no Brasil (Toledo \& Carvalho, 2017; Vidal \& Rabelo, 2019), mas aqui se trata de mostrar que a coleção dirigida por Lourenço Filho, com o apoio de Fernando de Azevedo, dá preferência à vertente europeia do escolanovismo em razão da colaboração dos professores franceses na produção dessa coleção.

Com o mercado editorial em rápida expansão, cria-se uma janela de oportunidades para círculos intelectuais já familiarizados com o universo dos autores, tradutores e editores em razão de seu trabalho pedagógico ou jornalístico. A editora Melhoramentos, em que publicaram vários educadores ligados à Escola Normal de São Paulo, abrigava uma coleção de livros infantis dirigida por um antigo inspetor da Escola Normal de São Paulo - Arnaldo de Oliveira Barreto - que provavelmente intermediou o contato entre a editora e Lourenço Filho ${ }^{56}$. A coleção Bibliotheca de Educação foi um fenômeno editorial para os padrões da época (Monarcha, 1997; Oliveira, 2015). Considerando-se os quatro primeiros anos da coleção, entre 1927 e 1930, observa-se que os autores traduzidos foram os professores franceses e suas redes europeias - círculo escolanovista que nesse momento investia na América Latina. Essa preferência pela vertente franco-suíça do escolanovismo é também uma estratégia de legitimação, pois se dá em detrimento da vertente norte-americana ${ }^{57}$.

de filosofia. Não digo de uma filosofia apriorística, mas do ponto de vista da cultura geral, de sentido humano de interpretação e de valoração. O ensino secundário me parece algo monstruoso. O sistema de créditos, permitindo a especialização precoce e a fragmentação dos estudos, parece-me uma solução muito simplista diante de um problema tão profundo." Lourenço Filho a Piéron. Nova York, $1^{\circ}$ jan. 1935. Cf. Fundo Piéron. Institut de Psychologie.

56. É possível que Fernando de Azevedo e Arnaldo Barreto tenham se conhecido no Rio de Janeiro, uma vez que ambos se mudam para a cidade na mesma época e vão trabalhar no Lloyd Brasileiro. Barreto nas escolas profissionais e Azevedo no setor de carregamentos. Barreto faleceu em 1925, mas possivelmente era bastante próximo a Lourenço Filho e a Fernando de Azevedo. Cf. Maziero, 2015.

57. Não se trata de afirmar que Lourenço Filho tenha se inspirado exclusivamente em autores franceses. Muito pelo contrário. Basta consultar suas publicações para concluir que suas referências bibliográficas são predominantemente norte-americanas. Não obstante, é inegável sua adesão à vertente europeia da psicologia a partir do diálogo que estabeleceu com Piéron. "Como suas lições e demonstrações já encontrassem em plena atividade núcleos de aplicação à educação e à organização do trabalho, foram 
Além de Lourenço Filho e de Fernando de Azevedo, os educadores desse círculo participaram de diversas formas do empreendimento: Sud Menucci tornou-se o responsável pelas resenhas críticas das obras no jornal OESP e Sampaio Doria foi o primeiro autor brasileiro a publicar na coleção.

Entre 1927 e 1930, a coleção publicou doze autores no total, entre os quais seis autores estrangeiros. Os seis autores traduzidos foram Henri Piéron (1927), Édouard Claparède (1928), Émile Durkheim (1929), Adolphe Ferrière (1929), Théodore Simon/Alfred Binet (1929) e John Dewey $(1930)^{58}$. Três deles haviam estado no Brasil nesse período através das missões, tais como Piéron (1923 e 1926), Simon (1929) e Claparède (1930), e os demais foram difundidos no país por Piéron e Fauconnet. Os autores europeus eram muito próximos entre si, pois pertenciam ao círculo intelectual que fundou a Liga Internacional da Educação Nova em $1921^{59}$. John Dewey foi o único autor estadunidense traduzido nessa primeira leva, em 1930, possivelmente após os contatos feitos por Anísio Teixeira durante sua estada nos Estados Unidos (Carvalho, 2000; Toledo \& Carvalho, 2017; Oliveira, 2015; Rocha, 2016; 2019).

As obras estrangeiras dessa coleção carregam outras marcas do trabalho necessário à legitimação dos educadores reformistas: traduções e prefácios. Entre as seis obras estrangeiras mencionadas, quatro foram traduzidas por Lourenço Filho - com exceção da obra de Ferrière, traduzida por Noemy Silveira Rudolfer, e de Dewey, por Anísio Teixeira ${ }^{60}$ - e cinco foram prefaciadas por ele ${ }^{61}$. Alguns prefácios foram

elas avidamente seguidas. Piéron teve oportunidade de oferecer não só princípios e técnicas de psicologia aplicada, como a discussão de problemas metodológicos, o que muito influiu na direção dos estudos de seus discípulos de então, entre os quais Roberto Mange, Lourenço Filho e Noemy Rudolfer". Cf. Lourenço Filho, 1956, p. 283.

58. Entre 1927 e 1930, a coleção da Melhoramentos publicou anualmente os seguintes volumes: 1 (1927), 4 (1928), 5 (1929) e 2 (1930). Cf. Oliveira, 2015.

59. Ferrière e Fauconnet eram, respectivamente, redator chefe e redator para a França da revista Pour l'Ère Nouvelle, publicada pela Liga Internacional da Educação Nova. Ferrière esteve em missão na América Latina e chegou a atracar no Brasil após passar por vários países, mas não pôde desembarcar em razão da revolução de 1930. Edouard Claparède e Adolphe Ferrière eram membros do Instituto Jean-Jacques Rousseu, em Genebra, e eram muito próximos a Piéron e a Dumas. Claparède colaborou com um capítulo no Traité de Psychologie de Dumas. Cf. Dumas a Claparède, Arquivos de Genebra. Sobre Claparède, cf. Ruchat, 2015.

60. Ao justificar a escolha de Anísio Teixeira como tradutor, Lourenço Filho afirma que ele era amigo e discípulo de Dewey. Ou seja, o tradutor não era um profissional da tradução, mas um discípulo. Cf. Oliveira, 2015, p. 88.

61. Lourenço Filho prefaciou 27 das 29 obras da coleção. Cf. Oliveira, 2015. O prefácio de Lourenço Filho aos Testes de Binet e Simon é revelador do diálogo ativo com os autores europeus. A tradução do volume é justificada pela "revisão da escala de Binet para as crianças paulistas, trabalho que vimos realizando há cerca de cinco anos [...]”. Cf. Lourenço Filho, 1920, p. 6. 
elaborados com base em material biográfico e bibliográfico enviado a Lourenço Filho pelos próprios autores. Ou seja, em seus primeiros anos, a coleção foi o resultado de uma troca constante entre os educadores reformistas e os professores estrangeiros, cujo resultado foi principalmente a difusão da sociologia durkheimiana e da psicologia experimental francesa, bem como da psicologia da infância praticada no Instituto Jean-Jacques Rousseau, na Suíça. A primeira obra de Durkheim traduzida no Brasil, Educação e Sociologia, foi prefaciada por Paul Fauconnet, com quem Lourenço Filho manteve correspondência. O prefácio de Fauconnet, em sintonia com a obra de Durkheim, criticava o escolanovismo estadunidense pelo seu caráter técnico, ou seja, pela ausência de preocupação com a relação entre escola e sociedade, e defendia que a consideração dos "meios" - a psicologia aplicada à educação - deveria se subordinar aos "fins sociais" estabelecidos por cada sociedade e, claro, pela sociologia. Os prefácios de Lourenço Filho exprimem a mesma concepção sobre a relação entre psicologia e sociologia - através do binômio "meios" e "fins"62. Defender o predomínio da sociologia em relação à psicologia representava uma tomada de posição clara: adesão à "teoria" em detrimento da "técnica” ou às ciências sociais europeias em detrimento do modelo norte-americano. Em relação à tiragem das obras estrangeiras, os volumes de Binet/Simon, Piéron e Durkheim estão entre as três mais reeditadas - indicador de que as obras francesas encontraram maior demanda entre os alunos das escolas normais.

A publicação dessas traduções gerou como contrapartida a prática do envio das obras dos educadores aos professores franceses. Tão logo publicavam suas próprias obras, os educadores as enviavam aos professores em busca de uma resenha crítica em alguma revista estrangeira ou comentário elogioso a ser publicado na própria obra em edição posterior ${ }^{63}$. Tomando-se como exemplo duas obras, uma de Lourenço Filho e outra de Fernando de Azevedo, observa-se a importância dessa prática: ambas contêm uma lista de autores estrangeiros com trechos elogiosos sobre a obra ${ }^{64}$. Essas

62. A superação da psicologia pela sociologia é descrita por Lourenço Filho: "O progresso das ciências naturais e, em particular, o desenvolvimento dos estudos psicológicos obrigaram os pedagogos à revisão de suas teorias tradicionais. Por outro lado, a transformação social dos últimos tempos, impondo novos problemas à cogitação de políticos e sociólogos, devia vir complicar essa reação-naturalista com uma reação crítica de sentido nitidamente social. A crise veio a envolver não só os problemas dos 'meios', mas o problema essencial dos 'fins' educativos”. Lourenço Filho, Prefácio a Claparède, 1928.

63. Os educadores também enviavam artigos para publicação no exterior. Veja-se, por exemplo, o artigo de Fernando de Azevedo no jornal L'Ére Nouvelle - dirigido por Ferrière (Vidal \& Rabelo, 2019; Vidal et al., 2020).

64. M. B. Lourenço Filho, Introdução ao estudo da Escola Nova, São Paulo, Melhoramentos, [1930] 1978; Fernando Azevedo, Princípios de sociologia, São Paulo, Companhia Editora Nacional, [1935] 1939. Fernando de Azevedo envia sua obra a Célestin Bouglé, que responde prometendo uma resenha nos Annales Sociologiques, o que não ocorreu possivelmente em razão da Segunda Guerra. Cf. Bouglé a Azevedo. IEB. 
listas selavam compromissos assumidos durante as missões e apostavam na difusão internacional do próprio nome. Na obra de Lourenço Filho (1930), Fauconnet, Piéron e Claparède, nessa ordem, são os primeiros da lista; o único autor estadunidense mencionado aparece em último lugar. Na obra de Fernando de Azevedo (1935) aparecem, em primeiro lugar, os sociólogos durkheimianos, e não há referências a autores estadunidenses. Assim, o reconhecimento almejado pelos dois educadores está orientado à Europa e não aos Estados Unidos. É da França, em particular, que pretendem obter os elogios necessários para fins de legitimação local.

No Brasil, defender a sociologia durkheimiana nos anos 1920 não era tarefa fácil. Em vários países havia um movimento crítico a Durkheim com base nos mesmos argumentos e referências bibliográficas, como Gabriel Tarde, René Worms, Henri Bergson e a psicologia social norte-americana. Ou seja, as teorias circulavam no espaço transnacional junto com suas concorrentes, inscrevendo-se em disputas locais associando-se a polos distintos. Desde a segunda metade dos anos 1920 alguns cursos de sociologia já adotavam referências teóricas norte-americanas - caso do Colégio Pedro il e da Escola Normal de Pernambuco (Leão, 1940; Meucci, 2007; Soares, 2015). Comparando-se, por exemplo, os manuais de Fernando de Azevedo (1935) e de Antônio Carneiro Leão (1940), conclui-se que ocupam posições opostas nos debates sobre a definição e a função das ciências do homem ${ }^{65}$. De fato, o círculo dos antidurkheimianos no país parece ter sido muito mais extenso do que o círculo dos durkheimianos, restritos ao círculo dos educadores de São Paulo, polos que serão renovados com a institucionalização das ciências sociais nas universidades dos anos 1930.

\section{Considerações finais}

As missões francesas dos anos 1920 foram fundamentais para estabelecer uma tradição de estudos em ciências do homem antes mesmo da fundação das universidades brasileiras. Enfatizei que é preciso considerar a importância de suas funções científicas, a despeito das diplomáticas, à medida que os professores franceses tinham interesse em se legitimar no espaço científico transnacional. Além disso, indiquei que as reformas educacionais e o movimento escolanovista no Brasil geraram uma demanda interna das elites dirigentes por modelos institucionais, curriculares e pedagógicos nos quais se inscreviam as ciências do homem. A afinidade de interesses

Lourenço Filho envia a Piéron sua obra Testes ABC [1933] e consegue uma notícia em L'Année Psychologique. Cf. L'Année Psychologique, 1933-2 - n. 1975.

65. Nos Princípios de sociologia, Durkheim é o autor central e o principal representante da sociologia científica. Sobre a inspiração durkheimiana dos manuais de sociologia, cf. Nascimento, pp. 270 e ss. Atualmente, preparo um estudo comparado sobre durkheimianos e antidurkheimianos nos anos 1930. 
entre professores franceses e educadores do círculo de São Paulo foi possível porque ambos os grupos ocupavam posição subordinada em seus campos de atuação - e eram dependentes da legitimação das novas ciências do homem nos respectivos contextos nacionais. O trabalho realizado pelos intermediários culturais fez com que circulassem obras e autores, teorias e métodos, modelos de sistemas e de políticas educacionais - categorias difundidas principalmente entre professores e alunos $\mathrm{da}$ Escola Normal de São Paulo, já familiarizados com alguma cultura científica. As manifestações públicas dos educadores mostram que, nesse período, suas preferências se redefinem e se orientam para as ciências do homem francesas em um contexto de rivalidade entre os próprios educadores reformistas.

Conforme registra a literatura sobre mobilidade internacional de professores nesse período, procurei mostrar a especificidade dos processos concomitantes de circulação de pessoas e de textos - ancorados em dois campos nacionais distintos e em suas respectivas posições no espaço transnacional. Assim, as relações de rivalidade entre a França, a Alemanha e os Estados Unidos são parte da explicação das missões francesas no Brasil. Em relação à circulação de teorias, é preciso considerar ainda as posições e as oposições dentro de cada espaço nacional, pois as teorias ou escolas não circulam isoladamente, mas em conjunto com as críticas de seus oponentes no campo de produção. Assim, as teorias ou escolas circulam num país estrangeiro associando-se aos interesses dos grupos intelectuais locais. Nesse sentido, é importante localizar a posição dos agentes tanto no campo da produção quanto no campo da recepção. Assim, entende-se o investimento dos psicólogos e dos sociólogos franceses no Brasil a partir da crise da universidade francesa e, em particular, das ciências do homem nesse período. Se, por um lado, a conquista de um público na América Latina exigia a exploração do capital simbólico representado pela cultura literária francesa, por outro lado, os interesses dos sociólogos e psicólogos iam além dessa dimensão. $\mathrm{O}$ peso de cada uma dessas práticas dependeu do tipo de trajetória intelectual no país de origem - orientada à acumulação de poder universitário (Dumas) ou à acumulação de capital científico (Piéron).

Em um espaço transnacional marcado pela desigualdade de recursos sociais e intelectuais, as posições no campo da recepção não deixam de trazer as marcas da dominação - a busca de legitimidade cultural ou científica por referência ao estrangeiro. Essas disposições podem ser identificadas em proporções diversas nas trajetórias das elites dirigentes brasileiras - dependendo da posição dominante ou dominada no campo do poder. Nesse sentido, a "importação" de modelos estrangeiros - institucionais, pedagógicos, teóricos - serviu tanto à distinção social quanto à legitimidade propriamente científica. A despeito da curta duração das missóes científicas, estabeleceram-se relações estruturadas e hierarquizadas por meio das quais se 
definiram preferências e referências bibliográficas - e não por leituras espontâneas inspiradas pelo contato imediato com fontes escritas. Assim, ao invés de se buscarem categorias "nativas" na história das ciências sociais no Brasil, vale mais explicitar as relações sociais concretas que as produziram.

\section{Referências Bibliográficas}

Azevedo, Fernando de. (1960), A educação na encruzilhada. 2 ed. São Paulo, Melhoramentos, vol. 4 Azevedo, Fernando de. (1939), Princípios de Sociologia. 3. ed. São Paulo, Companhia Editora Nacional, vol. 9.

Azevedo, Fernando de et al. ([1932] 2010), Manifesto dos Pioneiros da Escola Nova. Brasília, MEC. Bergson, Henri; Bérard, LÉon \& Besnard, Philippe. (1979), "Lettres de Bergson et de Bérard”. Revue Française de Sociologie, Les Durkheimiens. Études et documents réunis par Philippe Bésnard, 20-1: 268-272.

Bomeny, Helena. (2001), Os intelectuais da educação. Rio de Janeiro, Jorge Zahar.

Bourdieu, Pierre. (1984), Homo academicus. Paris, Éd. Minuit.

Bourdieu, Pierre (dez. 2002), "Les conditions sociales de la circulation internationale des idées". Actes de la Recherche en Sciences Sociales, 145.

Campos, Cristina de. (2007), Ferrovias e saneamento em São Paulo: o engenheiro Antônio Francisco de Paula Souza e a construção da rede de infraestrutura territorial e urbana paulista (1870-1893). São Paulo, FAU-UsP.

Carvalho, Marta Maria Chagas de. (1986), Molde nacional e fôrma civica: higiene, moral e trabalho no projeto da associação brasileira de educação (1924-1931). São Paulo, tese de doutorado, Faculdade de Educação da Universidade de São Paulo.

Charle, Christophe. (1994), "Ambassadeurs ou chercheurs ? Les relations internationales de professeurs de la Sorbonne sous la III ${ }^{\mathrm{e}}$ République”. Genèses, [s. l.], 14: 42-62. Disponível em https://www.persee.fr/doc/genes_1155-3219_1994_num_14_1_1212.

Charle, Christophe; Schriewer, Jürgen \& Wagner, Peter (org.). (2004), Transnational intellectual networks: forms of academic knowledge and the search for cultural identities. Frankfurt/Main, Campus Verlag.

Consolim, Marcia. (2008), “Posfácio: Gustave Le Bon e a Crítica da razão acadêmica”. In: LE Bon, Gustave. Psicologia das multidões. São Paulo, Martins Fontes. 
Consolim, Marcia. (2018), “Georges Dumas e Marcel Mauss: diálogo sobre a expressão das emoções e dos sentimentos”. In: Consolim, M.; Weiss, R. \& Pizarroso, N. (orgs.). Marcel Mauss: relaçôes reais e práticas entre a psicologia e a sociologia. São Paulo, Edusp, pp. 141-164.

Durkheim, Émile. (1929), Educação e Sociologia. Introdução de Paul Fauconnet, "A obra pedagógica de Durkheim”. Tradução de Lourenço Filho. São Paulo, Melhoramentos. Bibliotheca de Educação, vol. 5.

Fauconnet, Paul. (1929), “A obra pedagógica de Durkheim”. Introdução a: Durkheim, Émile. (1929), Educação e Sociologia. Tradução de Lourenço Filho. São Paulo, Melhoramentos. Bibliotheca de Educação, vol. 5, pp. 5-31.

Fauconnet, Paul. "Estrutura e Organização das Universidades Francesas". O Estado de S. Paulo, 12 de outubro de 1927.

Fauconnet, Paul. “A questão das humanidades". O Estado de S. Paulo, 9 maio 1928.

Geiger, Roger. (1979) "La sociologie dans les écoles normales primaires: Histoire d'une controverse”. Revue Française de Sociologie, 20-1: 257-267. Les Durkheimiens. Etudes et documents réunis par Philippe Besnard.

Godor, Lidiany Cristina de Oliveira. (2014), A reforma do ensino no estado de São Paulo: conflitos e disputas (1891-1892). Campinas, tese de doutorado, Faculdade de Educação da Universidade Estadual de Campinas, Unicamp.

Gomes, Clecia Aparecida. (2015), Os engenheiros da Associação Brasileira de Educação (ABE): confluências entre ideias educacionais e urbanas na cidade do Rio de Janeiro nos anos iniciais do século XX. Campinas, dissertação de mestrado, Instituto de Filosofia e Ciências Humanas da Universidade Estadual de Campinas, Unicamp.

Hamburguer, Amélia Império et al. (1996), A ciência nas relaçôes Brasil-França (1850-1950). São Paulo, Edusp/Fapesp.

Heilbron, Johan et al. (2009), "Internationalisation des sciences sociales: les leçons d'une histoire transnationale". In: SAPIRO, Gisèle. L'espace intellectuel en Europe: De la formation des États-nations à la mondialisation XIX'-XXI siècle. Paris, La Découverte, pp. 319-346.

Kovacevic, Gisele Schiavetti Basilio. (2019), A politica cultural francesa e o Lyceu Franco-Brasileiro S. Paulo como um modelo de ensino secundário para o Brasil - (1916-1951). São Paulo, dissertação de mestrado, Faculdade de Educação da Pontifícia Universidade Católica de São Paulo, PUC-SP.

Lamarão, Sérgio T. de N. (2012), A energia elétrica e o parque industrial carioca (1880-1920). Globalización, innovación e construcción de redes técnicas urbanas en América Latina y Europa (1890-1930). Simpósio Internacional, Universidade de Barcelona.

LEÃo, Antônio Carneiro. (1940), Fundamentos de sociologia. São Paulo, Melhoramentos.

Le Bon, Gustave. (2008), Psicologia das multidões. São Paulo, Martins Fontes.

Le Bon, Gustave. (1902), Psychologie de l'Éducation. Paris, E. Flammarion.

Limongi, Fernando. (1989), “Mentores e clientelas da Universidade de São Paulo”. In: Miceli, Sergio (org.). (1989), História das Ciências Sociais no Brasil - 1. São Paulo, Vértice, pp. 111-187. 
Massi, Fernanda. (1989), "Franceses e norte-americanos nas Ciências Sociais brasileiras (1930-1960)”. In: Miceli, Sergio (org.). História das Ciências Sociais no Brasil. São Paulo, Vértice.

Maziero, Maria das Dores S. (2015), Arnaldo de Oliveira Barreto e a Biblioteca Infantil Melhoramentos (1915-1925): Histórias de ternura para mãos pequeninas. Campinas, tese de doutorado, Faculdade de Educação da Universidade Estadual de Campinas, Unicamp.

Medeiros, Valéria A. (2005), Antonio de Sampaio Dória e a modernização do ensino em São Paulo nas primeiras décadas do século XX. São Paulo, tese de doutorado, Faculdade de Educação da Pontifícia Universidade Católica de São Paulo, PUC-SP.

Melo, Carolina S. B. de. (2016), Légitimation, application et formation: les missions scientifiques françaises au Brésil dans le domaine de la psychologie (1908-1947). Paris, tese de doutorado, École des Hautes Études en Sciences Sociales.

Melo, Carolina S. B. de \& Campos, Regina H. de F. (2014), "Scientific exchanges between France and Brazil in the History of Psychology. The role of Georges Dumas between 1908 and 1946". Universitas Psychologica, Bogotá, 13 (5): 1681-1695.

Meucci, Simone. (2007), "Entre a escola nova e a oligarquia: a institucionalização da sociologia na Escola Normal de Pernambuco - 1929-1930". Cronos, 8 (2): $451-474$.

Miceli, Sérgio. (2001), Intelectuais à brasileira. São Paulo, Companhia das Letras.

Miceli, Sérgio. (1989), História das Ciências Sociais no Brasil. São Paulo, Vértice/Revista dos Tribunais.

Monarcha, Carlos. (org.). (1997), "Lourenço Filho e a Biblioteca de Educação”. In: Lourenço Filho: outros aspectos, mesma obra. Campinas, Mercado de Letras, pp. 27-57.

Monarcha, Carlos. (2001), Lourenço Filho e a organização da psicologia aplicada à educação. Brasília, Inep.

Monarcha, Carlos. (2009), Brasil arcaico, Escola Nova. São Paulo.

Nagle, Jorge. (2006), “A educação na Primeira República”. In: Pinheiro, Paulo Sérgio et al. (orgs.). História geral da civilização brasileira: O Brasil republicano. 8 ed. Rio de Janeiro, Bertrand Brasil, t. III, vol. 9, pp. 283-318.

Nagle, Jorge. (2009), Educação e sociedade na Primeira República. São Paulo, Edusp.

Nascimento, Alessandra Santos. (2012), Fernando de Azevedo: Dilemas na institucionalização da sociologia no Brasil. São Paulo, Cultura Acadêmica.

Nery, Ana Clara Bortoleto. (2008), A Sociedade de Educação de São Paulo: Embates no campo educacional (1922-1931). São Paulo, Unesp.

Oliveira, Priscila M. (2015), Lourenço Filho e a coleção biblioteca de educação: uma análise dos prefácios escritos por esse educador. São Carlos, dissertação de mestrado, PPG Educação/ Cech, Universidade Federal de São Carlos, ufscar.

Petitjean, Patrick. (1989), “Le Groupement des Universités et Grandes Écoles de France pour les relations avec l'Amérique Latine et la création d'Instituts à Rio, São Paulo et Buenos 
Aires (1907/1940)". In: D’Ambrósio, Ubiratan. Anais do 2 Congresso Latino-Americano de História da Ciência e da Tecnologia. São Paulo, Nova Stella, pp. 428-442.

Pontes, José Alfredo Vidigal. (2010), Júlio de Mesquita Filho. Recife, Fundação Joaquim Nabuco, Massangana.

Rocha, Ana Cristina S. M. (2016), Experiências norte-americanas e projetos de educação no Distrito Federal e em São Paulo (1927-1935): Anisio Teixeira, Noemi Silveira, Isaías Alves e Lourenço Filho. Rio de Janeiro, tese de doutorado em História das Ciências e da Saúde, Fundação Oswaldo Cruz, Casa de Oswaldo Cruz, Fiocruz.

Rocha, Ana Cristina S. M. (2019), "Noemy Silveira, Isaías Alves e a psicologia educacional: diálogos entre Brasil, França e EUA". História, Ciências, Saúde - Manguinhos, Rio de Janeiro, 26 (2): 407-425.

Ruchat, Martine. (2015), Édouard Claparède: à quoi sert l'éducation. Lausanne, Antipodes. SANGLARD, Gisele. (2008), Entre os salóes e o laboratório: Guilherme Guinle, a Saúde e a Ciência no Rio de Janeiro, 1920-1940. 20 ed. Rio de Janeiro, Editora Fiocruz.

SAntos, Heloisa Helena Meirelles dos. (2013), "Escola Normal do Distrito Federal: por trás da modernidade civilizatória da cidade do Rio de Janeiro (1911-1920)”. Revista Contemporânea de Educação, Rio de Janeiro, 8 (15): 135-155.

Santos, José Fagner Alves. (2018), Júlio de Mesquita Filho e o projeto de ensino superiorpaulista: seus escritos, sua atuação (1920-1938). São Paulo, dissertação de mestrado, Faculdade de Educação da Pontifícia Universidade Católica de São Paulo, PUC-SP.

SAVOYE, Antoine. (2007), "La science de l'éducation face à la réforme des lycées (France, 19201939)". Symposium "Science(s) de l'éducation et République face à face. Théorisations contrastées d'une discipline indisciplinée (fin du 19e-20e)".

Silva, André F. C. (2011), A trajetória científica de Henrique da Roch a Lima e as relações Brasil-Alemanha (1901-1956). Rio de Janeiro, tese de doutorado em História das Ciências e da Saúde, Casa de Oswaldo Cruz, Fiocruz.

Souza, Letícia Pumar Alves de. (2015), A ciência e seus fins: internacionalismo, universalismo e autonomia na trajetória do fisiologista Miguel Ozório de Almeida (1890-1953). Rio de Janeiro, tese de doutorado em História das Ciências e da Saúde, Casa de Oswaldo Cruz, Fiocruz.

SoAres, Jefferson da Costa. (2015), “A construção do currículo de sociologia no colégio Pedro II (1925-1941)". Cadernos de História da Educação, 14 (1): 95-113.

Suppo, Rogelio Hugo. (2001), La politique culturelle française au Brésil entre les années 19201950. Paris, tese de doutorado, Paris III.

Terral, Hervé. (2008), Les manuels de Sociologie dans Les Écoles Normales D'instituteurs (1920-1940). In : Trois figures de l'école durkheimienne: Celestin Bouglé, Georges Davy, Paul Fauconnet. L'Harmattan. Dir. Claude Ravellet et Louis Ferraz. Imec, Anamnese, 3, pp. $39-56$.

Terral, Hervé. (2005), "Paul Lapie (1869-1927): universitaire et bâtisseur de l'école laïque”. Carrefours de l'Éducation, 1 (19): 121-137. 
Vidal, Diana Gonçalves. (2013), "80 anos do Manifesto dos Pioneiros da Educação Nova: questões para debate”. Educação e Pesquisa, São Paulo, 39 (3): 577-588.

VidAl, Diana G. \& RABELo, Rafaela S. (jan.-abr. 2019), “A criação de Institutos de Educação no Brasil como parte de uma história conectada da formação de professores". Cadernos de História da Educação, 18 (1): 208-220.

Vidal, Diana G.; Silva, José C. S. \& Abdala, Raquel. (2020), Fernando de Azevedo em releituras. Sobre lutas travadas, investigaçôes realizadas e documentos guardados. São Paulo, Paco.

Vercesi, Maria Elena de Abreu. (2010), O Lyceu Franco-Brasileiro São Paulo. São Paulo, dissertação de mestrado. Faculdade de Educação da Pontifícia Universidade Católica de São Paulo, PUC-SP.

WARDE, Mirian Jorge. (2003), “O itinerário de formação de Lourenço Filho por descomparação”. Revista Brasileira de História da Educação, 5: 125-167.

WeID, Elisabeth Von der. (1989), A expansão da Rio de Janeiro Tramway Light and Power ou as origens do "Polvo Canadense. Trabalho apresentado no $10^{\circ}$ Módulo do Congresso Internacional do Centenário da República Brasileira. Rio de Janeiro, 28 set. 1989. Mesa Redonda "Energia Elétrica, Estado e Sociedade". Mimeo. Rio de Janeiro, Fundação Casa de Rui Barbosa, pp. 1- 49.

\section{Resumo}

Circulação de intelectuais e recepção das novas ciências do homem francesas no Brasil: 1908-1932 Trata-se de mostrar que as missões científicas francesas no Brasil tiveram um papel fundamental de enraizamento das ciências do homem francesas nas décadas que antecederam a fundação das universidades nos anos 1930. No contexto das disputas entre França e Estados Unidos pela dominação cultural e científica na América Latina, a estratégia dos professores franceses foi estabelecer relações sociais e práticas de difusão cultural e científica nos meios social e intelectualmente dominantes. Essas iniciativas foram bem-sucedidas graças à homologia de posição entre os professores franceses e os educadores do círculo intelectual de São Paulo - o que contribuiu para o distanciamento relativo dos educadores em relação às elites dirigentes. Concluo que a circulação das ciências do homem francesas encontrou barreiras dentro do próprio campo educacional, ditadas pelo crescente espírito antidurkheimiano.

Palavras-chave: Georges Dumas; Missões científicas francesas; Educadores reformistas; Ciências do homem. 


\section{Abstract}

Circulation of intellectuals and reception of the new French human sciences in Brazil: 1908-1932 This article aims to show that the French scientific missions in Brazil had a fundamental role in rooting the French human sciences in the decades before the foundation of universities in the 1930s. In the context of the disputes between France and the United States for cultural and scientific domination in Latin America, the strategie of French teachers was to establish social relations and practices of cultural and scientific diffusion in socially and intellectually dominant milieus. These initiatives were successful thanks to the homology of position between French teachers and educators in the intellectual circle of São Paulo - which contributed to the relative distance between educators and the ruling elites. I conclude that the circulation of the French social sciences encountered barriers within the educational field itself, dictated by the growing anti-Durkheimian spirit.

Keywords: Georges Dumas; French scientific missions; reformist eductors, human sciences. Texto recebido em 20/7/2020 e aprovado em 24/8/2020.

DOI: 10.11606/0103-2070.ts.2021.172634.

Marcia Consolim é professora da Escola de Filosofia, Letras e Ciências Humanas da Universidade Federal de São Paulo - EFLCH/Unifesp. É membro do Instituto Brasileiro de Estudos Durkheimianos (UfRgs). Coordena o Grupo de Estudos e Pesquisas SCICI - Science in Circulation no Instituto de Estudos Avançados e Convergentes da Unifesp. Atualmente, desenvolve projeto de pesquisa sobre a circulação de intelectuais e das ciências sociais entre a França, Brasil e Estados Unidos na primeira metade do século xx.E-mail: mconsolim@terra.com.br. 